DISEASE, DEMOGRAPHY, AND DIET IN EARLY COLONIAL NEW SPAIN: INVESTIGATION OF A SIXTEENTH-CENTURY MIXTEC CEMETERY AT TEPOSCOLULA YUCUNDAA Author(s): Christina Warinner, Nelly Robles García, Ronald Spores and Noreen Tuross Source: Latin American Antiquity, Vol. 23, No. 4 (December 2012), pp. 467-489

Published by: Society for American Archaeology

Stable URL: http://www.jstor.org/stable/23645608

Accessed: 26-09-2016 09:31 UTC

JSTOR is a not-for-profit service that helps scholars, researchers, and students discover, use, and build upon a wide range of content in a trusted digital archive. We use information technology and tools to increase productivity and facilitate new forms of scholarship. For more information about JSTOR, please contact support@jstor.org.

Your use of the JSTOR archive indicates your acceptance of the Terms \& Conditions of Use, available at http://about.jstor.org/terms

Society for American Archaeology is collaborating with JSTOR to digitize, preserve and extend access to Latin American Antiquity 


\title{
DISEASE, DEMOGRAPHY, AND DIET IN EARLY COLONIAL NEW SPAIN: INVESTIGATION OF A SIXTEENTH-CENTURY MIXTEC CEMETERY AT TEPOSCOLULA YUCUNDAA
}

\author{
Christina Warinner, Nelly Robles García, Ronald Spores, and Noreen Tuross
}

\begin{abstract}
A mid-sixteenth-century cemetery was investigated at the colonial Mixtec site of Teposcolula Yucundaa and is shown to be related to the cocoliztli pandemic of 1544-1550. This is the earliest colonial epidemic cemetery to be identified in Mexico. Through archaeogenetic and oxygen stable isotope analysis it is demonstrated that the interred individuals were local Mixtecs, and mortuary analysis sheds light on both Christian and traditional religious practices at the site. Mitochondrial haplogroup frequencies support long-term genetic continuity in the region, and carbon stable isotopes of bone collagen and enamel carbonates suggest no decrease in maize consumption during the early colonial period, despite historical evidence for a changing agricultural economy and increased wheat production at the site. The Teposcolula cemetery provides a rich and complex perspective on early colonial life in the Mixteca Alta and reaffirms the importance of archaeological and bioarchaeological evidence in investigating complex social and biological processes of the past.
\end{abstract}

Se investigó un cementerio mixteco de mediados del siglo diciseis en el sitio arqueológico de PuebloViejo de Teposcolula Yucundaa, el cual está aparentemente relacionado con la pandemia de cocoliztli de 1544-1550. Se demuestra mediante el análisis de ADNmt antiguo y de isótopos de oxígeno estable que los individuos enterrados son mixtecos locales. El análisis del tratamiento mortuorio de los entierros nos informa sobre las prácticas religiosas tanto cristianas como prehispánicas del lugar. El análisis de las frecuencias relativas de haplogrupos mitocondriales demuestra la continuidad genética que tuvo lugar en esta región. Los isótopos estables de carbono indican que no hubo un descenso en el consumo de maíz durante la primera parte de la época colonial, a pesar de que las evidencias históricas sugieren un cambio en la economía agrícola y un aumento de la producción de trigo. El cementerio de Teposcolula proporciona una rica y compleja perspectiva sobre la vida al comienzo de la época colonial en la Mixteca Alta y reafirma la importancia de la evidencia arqueológica y bioarqueológica en la investigación de procesos sociales y biológicos ocurridos en el pasado.

I $\mathrm{n}$ the fifteenth through seventeenth centuries, collectively known as the Age of Exploration, European nations embarked on great long-distance voyages and claimed vast new, but not empty, territories as subject colonies. Among the most ambitious of these nations was Spain, whose conquistadores sought to discover, conquer, pacify, and settle new lands. Eventually, Spanish holdings came to encompass nearly half of the American continents.

In Mesoamerica, the early colonial period brought many changes to native communities: new taxation and labor requirements; missionaries, colonists, and slaves from diverse parts of the empire; epidemic disease; the introduction of wheat and other European crops; the establishment of new industries such as sericulture (silkworm-raising) and herding; and a fundamental reorganization of political, spiritual, and social power. Not all indigenous communities bore these changes well, and by the mid-seventeenth century, many onceprosperous communities had failed, victims of massive population decline, environmental degradation, and economic collapse (Melville

\footnotetext{
Christina Warinner = Department of Anthropology, Harvard University, Cambridge, MA 02138 (warinner@post.harvard.edu) ${ }^{1}$

Nelly Robles García — National Institute of Anthropology and History, Monte Albán Archaeological Zone, Oaxaca, Mexico 68140 (nellym_robles@yahoo.com.mx)

Ronald Spores • Professor Emeritus, Vanderbilt University, Depoe Bay, OR 97341 (ronoaxaca@hotmail.com)

Noreen Tuross - Department of Human Evolutionary Biology, Harvard University, Cambridge, MA 02138 (tuross@fas.harvard.edu)
}

Latin American Antiquity 23(4), 2012, pp. 467-489

Copyright (C)2012 by the Society for American Archaeology 
1994; Miranda 1958; Romero Frizzi 1990; Terraciano 2001).

In the Mixteca Alta, historians have theorized that epidemic disease and depopulation facilitated Spanish land seizure and paved the way for intensive pastoralism by inducing labor shortfalls and creating vast stretches of fallow land. The shortage of peasant labor needed to maintain agricultural terraces and to work the rich fields of the valleys facilitated the relocation of towns to the valleys under congregación, a new colonial policy of forced resettlement. This in turn freed up formerly occupied mountain slopes for grazing and led to erosion, soil infertility, and the eventual agricultural collapse of what had once been described by the Spanish as the land of milk and honey (de Burgoa 1934 [1674]; Pérez Rodríguez 2006; Terraciano 2001).

The roots of this process can be traced to the sixteenth century, when Spanish missionaries and colonists first established themselves in the Mixteca; however, direct evidence of the key factors in this process is wanting. For example, although it has long been recognized that Spanish control of colonial territories greatly expanded following catastrophic population loss from introduced epidemic disease (Cook 1998; Cook and Borah 1968; Diamond 1997; Humboldt 1811; Prem 1992; Zinsser 1934), little physical evidence of the epidemics has been found. Many towns in the Mixteca were successfully relocated under congregación, but the proximate causes of these moves have not been established. Spanish missionaries and colonists were present in the Mixteca, but their numbers and influence within local communities are poorly understood. Historical records of taxation and tithing document a changing economy and the cultivation of European crops, but no archaeological studies have confirmed this fact. Direct archaeological investigation is needed in order to better understand these issues and test the conclusions drawn from the historical record.

In this article, we describe the discovery of a unique colonial cemetery at the Mixtec site of Teposcolula Yucundaa. Using mortuary and paleodemographic analysis, we draw a connection between the cemetery and the 1544-1550 cocoliztli epidemic and determine through oxygen stable isotope and ancient DNA analysis that the cemetery contains local Mixtecs, finding no evidence for long-distance migrants or nonindigenous individuals. We then use carbon and nitrogen stable isotope analysis to test the hypothesis that the changing colonial economy affected local cultivation and food consumption patterns and find that continuity, rather than change, characterizes the early colonial subsistence economy. Taken together, the bioarchaeological analyses performed in this study provide some of the earliest physical evidence of epidemic disease in the Spanish-controlled territories of the New World and yield new insights into early colonial indigenous culture and economy in the Mixteca.

\section{Site Background}

The archaeological site of Teposcolula Yucundaa is located in southern Mexico on a mountain ridge in the highland Mixteca Alta region of Oaxaca (Figure 1)..$^{2}$ At its prehispanic height, Teposcolula Yucundaa controlled a territory of approximately $500 \mathrm{~km}^{2}$ with an estimated population of up to 60,000 (Balkansky et al. 2000; Stiver 2001). Its urban core, with an estimated population of $7,000-8,000$, covered 250 ha and was ringed by a 2-km-long raised road that enclosed numerous structures and features, including a royal compound, elaborate stone masonry civic-ceremonial buildings, multiple paved plazas, more than 30 "palaces," a ball court, and more than 1,000 residential terraces (Balkansky et al. 2000; Spores and Robles García 2007; Stiver 2001).

The late Postclassic and early colonial chronology of Teposcolula is now well established (Spores and Robles García 2007). Teposcolula was a subject of the Aztec Triple Alliance from 1458 to 1520 (Berdan and Anawalt 1997; Chimalpahin 1997 [ca. 1621]) and was later incorporated into the Spanish crown following the conquest of Tenochtitlán in 1521. At least six parties of early Spanish explorers and conquistadores passed through the region from 1520 to 1525 (Oudijk and Restall 2007), and after being briefly held in private trust (encomienda), Teposcolula was reclassified as a public corregimiento in 1531 (Chance 1978). An epidemic of smallpox struck the Mixtec Alta region in the early 1530s (Acuña 1984), and in 1538 Dominican friars successfully founded a mission (vicaria) at the site and constructed a large stone church and monastery complex (Spores and Robles García 2007). 


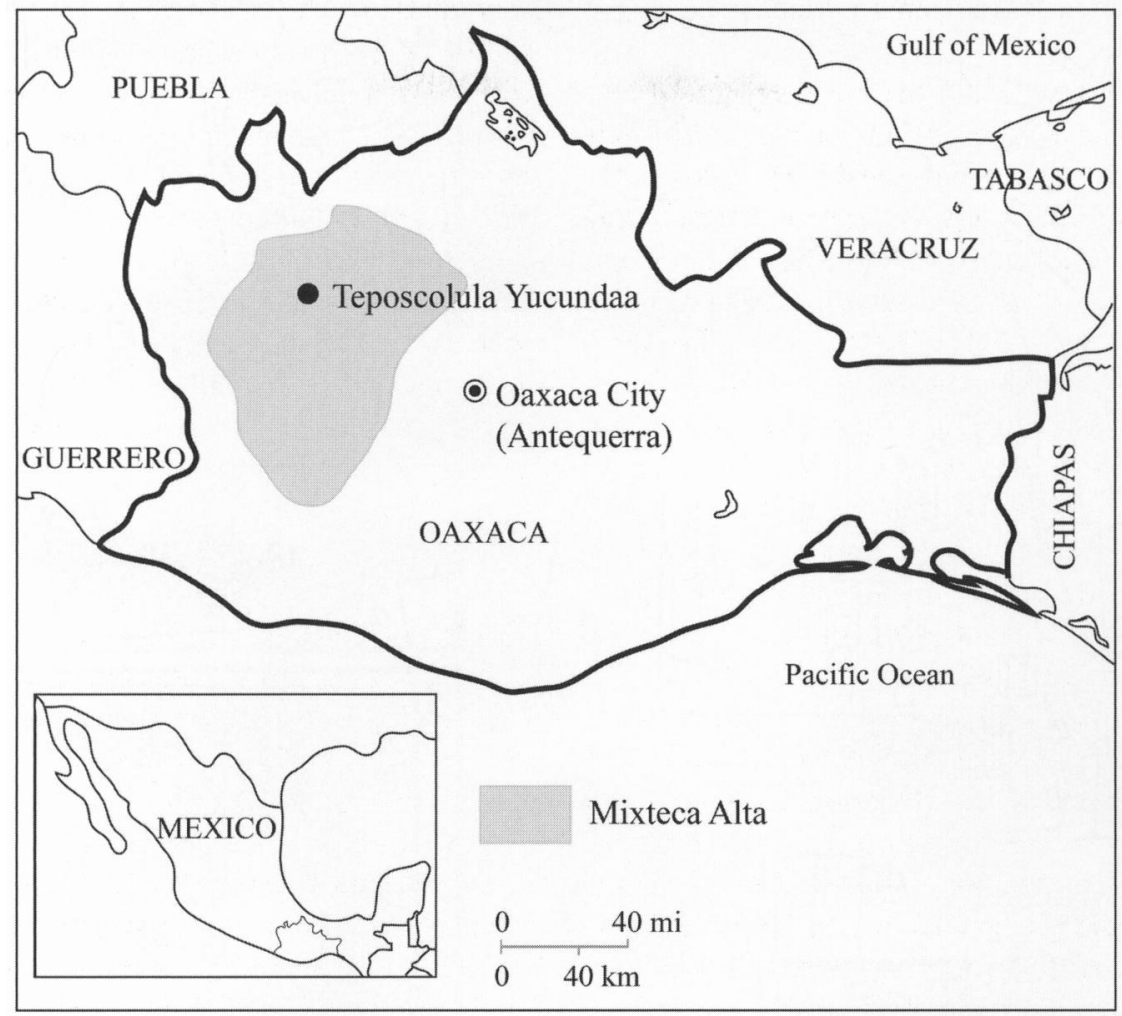

Figure 1. Location of Teposcolula Yucundaa within the Mixteca Alta region of the southern Mexican state of Oaxaca.

Following the failure of a mission at the neighboring site of Yanhuitlán in 1542, Teposcolula Yucundaa became the focal point of Dominican missionary efforts in the Mixteca Alta, hosting a high-profile Inquisition trial from 1544 to 1546 (Jiménez Moreno and Mateos Higuera 1940; Pérez Ortiz 2003) and serving as the primary residence for at least 15 different Dominican friars between 1538 and 1552 (Mullen 1975; Vences Vidal 2000). Spanish-style features began appearing in high-status Mixtec architecture at this time in the form of arched doorways, pivoting doors, and exterior wall friezes depicting European motifs (Spores and Robles García 2007). At the same time, Spanish colonists began settling in the Mixteca Alta, where they established burgeoning sericulture and livestock-herding industries. By 1544 , Teposcolula was one of the largest producers of silk in the entire Mixteca, producing approximately 2,000 Spanish pounds (libras) of silk annually (Borah 1963).

Forced resettlement under congregación was introduced in the 1540s, and the Dominicans began planning the relocation of Teposcolula to a new Spanish-style town in the valley below. In 1545 or 1546 another major epidemic struck the Mixteca Alta region, and in 1552, the town was formally moved to the valley by direct order of the viceroy (Gerhard 1977; Zavala 1982). The new town, later christened San Pedro y San Pablo Teposcolula, was elevated to the status of a regional capital (alcaldía mayor), and records from the 1560s and 1570s document numerous Spanish residents (Calderón Galván 1988; Romero Frizzi 1990). The former mountaintop urban core of Teposcolula Yucundaa, known locally as Pueblo Viejo, has remained unoccupied to the present.

\section{Excavation of the Grand Plaza and Churchyard}

Excavations began at the site of Teposcolula Yucundaa in 2004 under the direction of Dr. Ronald Spores and Dr. Nelly Robles García. To date, many areas of the site have been explored (Figure 2), including the Dominican church and monastery, the 

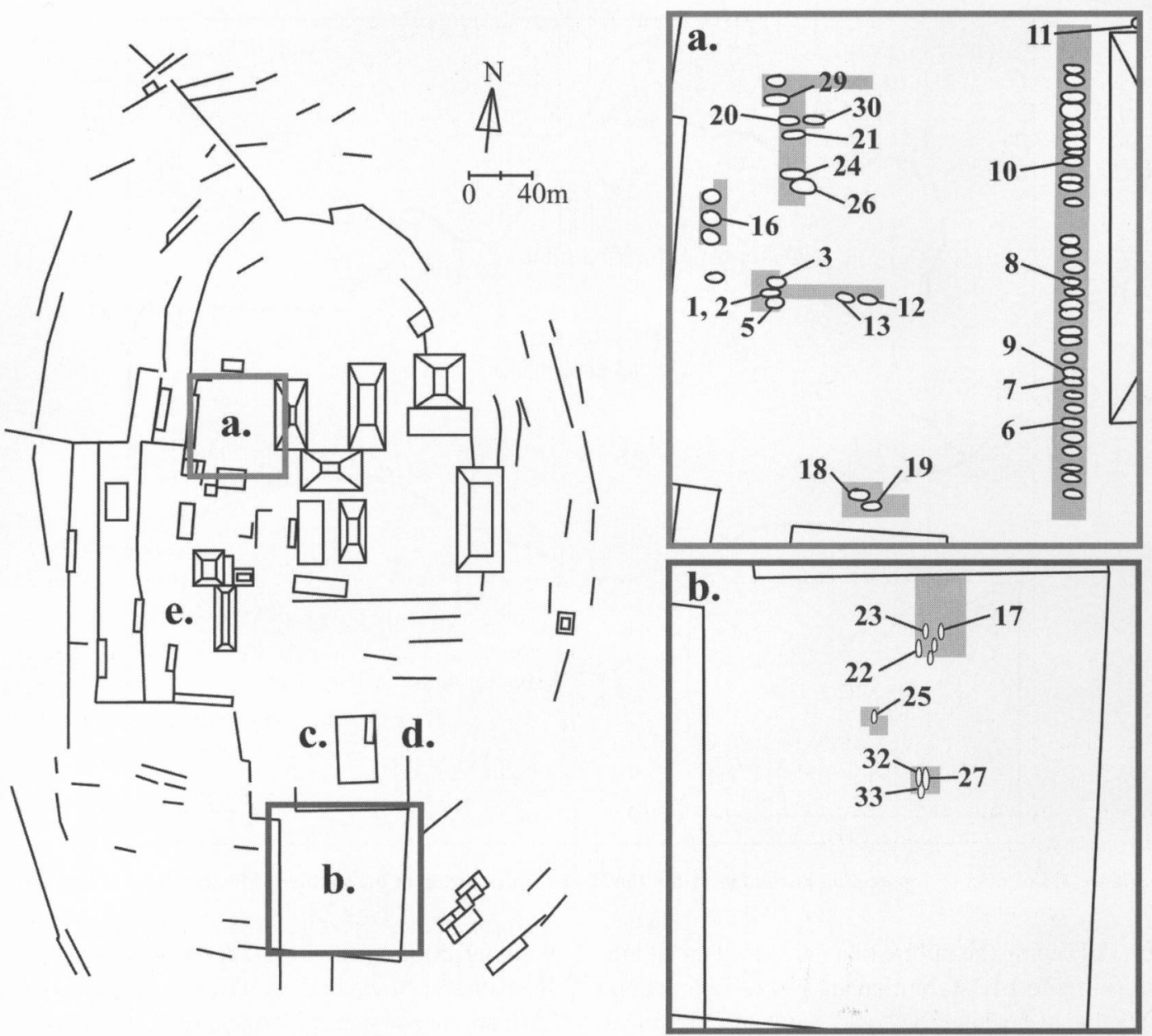

Figure 2. Central zone of Teposcolula with enlarged insets of (a) the Grand Plaza and (b) the churchyard. The (c) church, (d) monastery, and (e) royal residence are also indicated. Insets are drawn to different scales; areas explored from 2004 to $\mathbf{2 0 0 6}$ are highlighted in gray, and excavated burials subjected to ancient DNA and isotopic analyses are numbered (map modified from Stiver 2001).

churchyard, administrative buildings and plazas, the royal palace, elite residences, commoner residences, and agricultural terraces (Robles García and Spores 2004, 2005, 2006; Spores and Robles García 2007). Numerous simple pit burials were found cut into the plaster floor of the Grand Plaza, the administrative center of the site. After additional excavation, it became clear that the Grand Plaza had functioned as a massive cemetery shortly before the site's abandonment in 1552 (Spores and Robles García 2007). Given the number of grave cuts observed per excavated square meter and the average number of individuals per excavated grave, the Grand Plaza cemetery may contain more than
800 individuals. Excavation of the walled churchyard revealed that it too contained burials. Given the location and treatment of the burials, the churchyard assemblage was initially assumed to also date to the colonial period (Warinner 2010); however, subsequent radiocarbon dating revealed that the interments predate the colonial period by a century (Table 1). Two additional Postclassic infant burials were recovered from residential features in outlying terraces. From 2004 to 2006, 30 burials containing 56 individuals were recovered from five areas of the Grand Plaza (Figure 2a), three areas of the churchyard (Figure $2 b$ ), and two outlying residential terraces. 
Table 1. Radiocarbon Dates for Teposcolula Human Remains.

\begin{tabular}{lcccc}
\hline $\begin{array}{l}\text { Individual Bone } \\
\text { Collagen Sample }\end{array}$ & $\begin{array}{c}\text { Sample } \\
\text { ID }\end{array}$ & $\begin{array}{c}\delta^{13} \mathrm{C} \\
(\%)\end{array}$ & $\begin{array}{c}{ }^{14} \mathrm{C} \text { Age } \\
\text { (years B.P.) }\end{array}$ & $\begin{array}{c}\text { Calibrated } \\
\text { Age (A.D.) }\end{array}$ \\
\hline $\begin{array}{l}\text { Grand Plaza cemetery } \\
22\end{array}$ & OS-83881 & -7.6 & $365 \pm 30$ & $1448-1634$ \\
Churchyard cemetery & & & & \\
32 & OS-80882 & -8.6 & $530 \pm 30$ & $1320-1440$ \\
42 & OS-80885 & -6.6 & $590 \pm 25$ & $1301-1412$ \\
45 & OS-80887 & -8.2 & $615 \pm 25$ & $1295-1400$ \\
48 & OS-80888 & -8.3 & $490 \pm 30$ & $1403-1450$ \\
Residential terrace & & & & \\
29 & & & & $1265-1389$ \\
\hline
\end{tabular}

Note: Calibration performed using OxCal 4.1, IntCal09 calibration; 95.4\% confidence interval.

\section{Methods}

\section{Collection of Mortuary and Paleodemographic Data}

Mortuary data including body orientation, placement, and position were recorded for 30 burials in the Grand Plaza and churchyard, as well as two burials in outlying residential terraces, and 56 individuals were examined for age, sex, and trauma/pathology indicators. Although several studies have commented on the poor quality of bone preservation in parts of Mexico (e.g., Duncan et al. 2008; Hodges 1987; Mansell et al. 2006; Tiesler et al. 2004), the gross preservation of skeletal remains at Teposcolula was excellent, in part owing to the cool and mild climate of the high-elevation Mixteca Alta region, which is situated at the intersection of the Sierra Madre Occidental and Sierra Madre del Sur mountain ranges (Pérez Rodríguez et al. 2011).

Forty-two individuals could be assigned sex on the basis of pelvic and cranial features (Buikstra and Ubelaker 1994; Salas 1982). Age was estimated on the basis of dental development, epiphyseal union, and degeneration of the pubic symphysis and auricular surface (Buikstra and Ubelaker 1994; Krogman and Iscan 1986; Lovejoy et al. 1985; Ubelaker 1989). Fifty individuals were fully examined for age indicators, and six individuals were assigned to basic age categories on the basis of field examination. Incisor shoveling, a frequent dental trait among indigenous American and Asian populations (Scott and Turner 1997), was common. No evidence of recent trauma was observed among the skeletons, although healed limb fractures were observed in at least three individuals. In general, the individuals exhibited a low incidence of skeletal pathologies, with arthritis and dental caries being the most common pathologies observed. Only one subadult presented evidence of a life-threatening illness, an advanced infection of the cervical vertebrae and kyphosis.

\section{Ancient DNA Extraction,}

\section{Amplification, and Sequencing}

All ancient DNA extraction and polymerase chain reaction (PCR) setup was performed in a dedicated ancient DNA laboratory at Harvard University. Standard ancient DNA laboratory procedures were followed throughout the extraction procedure to prevent contamination and to verify results (Warinner 2010). DNA was extracted from 48 human bone samples, and ancient DNA extracts were PCR amplified with newly developed primer sets (Table 2) designed to detect mitochondrial coding-region polymorphisms that define macrohaplogroups $\mathrm{N}$ and $\mathrm{M}$ and haplogroups $\mathrm{A}, \mathrm{B}, \mathrm{C}$, and D (Kolman and Tuross 2000; Torroni et al. 1993).

All 48 individuals tested in this study yielded amplifiable DNA. A minimum of four mitochondrial target regions were successfully amplified for each individual, and 33 individuals amplified all five target regions in this study. Of the 227 successful amplifications, only five exhibited an ambiguous base at a single nucleotide polymorphism position of interest. These samples were reamplified and in all cases yielded a clear and unambiguous base identification. An additional 22 individuals were further subjected to reamplifica- 
Table 2. Mitochondrial Coding Region Primers.

\begin{tabular}{|c|c|c|c|c|c|c|}
\hline Primer & Marker & Significance & $\begin{array}{l}\mathrm{TA} \\
\left({ }^{\circ} \mathrm{C}\right) \\
\end{array}$ & Sequence $\left(5^{\prime}-3^{\prime}\right)$ & $\begin{array}{l}\text { Amplicon } \\
\text { Length (bp) }\end{array}$ & Reference \\
\hline NMF-10363 & $10398 \mathrm{~A}$ & MHg N & 49 & TGGCCTATGAGTGACTACAA & 118 & This study \\
\hline NMR-10480 & $10400 \mathrm{~T}$ & MHg M & & ATGAGGGGCATTTGGTAAATAT & & Kolman and Tuross 2000 \\
\hline AF-00635 & $663 \mathrm{G}$ & $\mathrm{Hg} \mathrm{A}$ & 49 & CACCCCATAAACAAATAGGTTTGG & 118 & This study \\
\hline AR-00745 & & & & TTGATCGTGGTGATTTAGAGG & & Kolman and Tuross 2000 \\
\hline BF-08196 & $8281-8289 \mathrm{del}$ & $\mathrm{Hg} \mathrm{B}$ & 47 & ACAGTTTCATGCCCATCGTC & $121 / 112$ & Kolman and Tuross 2000 \\
\hline BR-08316 & & & & ATGCTAAGTTAGCTTTACAG & & Kolman and Tuross 2000 \\
\hline CF-13239 & $13263 \mathrm{G}$ & $\mathrm{Hg} \mathrm{C}$ & 51 & CGTAGCCTTCTCCACTTCAAGT & 128 & This study \\
\hline CR-13366 & & & & CGGTGCACATAAATAGTATGGCT & & This study \\
\hline DF-05150 & $5178 \mathrm{~A}$ & $\mathrm{Hg} \mathrm{D}$ & 51 & ССТАСТАСТАТСТСGCACСТG & 125 & Kolman and Tuross 2000 \\
\hline DR-05274 & & & & CTTCGATAATGGCCCATTTGGG & & This study \\
\hline
\end{tabular}

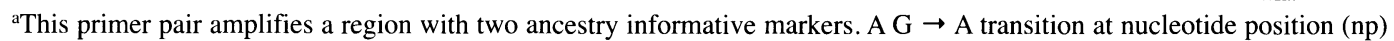
10398 is characteristic of macrohaplogroup $\mathrm{N}$, which includes haplogroups A and $\mathrm{B}$, while a $\mathrm{C} \rightarrow \mathrm{T}$ transition at $\mathrm{np} 10400$ is characteristic of macrohaplogroup $\mathrm{M}$, which includes haplogroups $\mathrm{C}$ and $\mathrm{D}$.

tion for at least one target and in all cases yielded consistent results.

\section{Stable Isotope Analysis $(C, N, O)$}

Bone collagen was isolated from tibia or femur shaft samples and analyzed for $\delta^{13} \mathrm{C}, \delta^{15} \mathrm{~N}$, and $\delta^{18} \mathrm{O}$ according to the methods described in Warinner and Tuross $(2009,2010)$, omitting the chloroform:methanol step, which is unnecessary for ancient samples. For comparative purposes, additional bone samples were collected from five prehispanic sites in the Valley of Oaxaca and analyzed for $\delta^{13} \mathrm{C}$ and $\delta^{15} \mathrm{~N}$ (Table 3; Warinner 2010). C/N for all bone collagen samples fell within the commonly accepted range for intact, biological collagen (DeNiro 1985).

Enamel apatite was collected from third molars and analyzed for carbonate $\delta^{13} \mathrm{C}$ and $\delta^{18} \mathrm{O}$ according to the methods described in Warinner and Tuross 2009. The third molar (M3) is the last tooth of the dentition to form, with crown formation primarily occurring between ages 10 and 12 and eruption between ages 15 and 21 (Ubelaker 1989). Heavy dental wear and antemortem tooth loss among older adults reduced the number of third molars available for analysis. Carbonate samples from the Grand Plaza plaster floors were also sampled and analyzed to determine the $\delta^{13} \mathrm{C}$ of local environmental carbonate sources. Because adsorbed carbonates can affect the isotopic ratios of archaeological apatites (Koch et al. 1997; Trueman et al. 2004), a duplicate aliquot of each sample was soaked for 50 minutes in a $1 \mathrm{M}$ acetic acid solution to remove loosely bound carbonates. Com- parison of the untreated and treated apatite aliquots yielded no significant difference in either $\delta^{13} \mathrm{C}$ or $\delta^{18} \mathrm{O}(p>.1$, ANOVA), and minimal pairwise differences between the two aliquots $(.1 \pm .6 \%$ in $\delta^{13} \mathrm{C}$ and $.3 \pm 1.3 \%$ in $\delta^{18} \mathrm{O}$ ) suggest that the archaeological enamel has undergone little exchange with carbonate sources in the immediate environment.

\section{Mortuary and Demographic Analysis of the Teposcolula Skeletal Assemblages}

\section{Grand Plaza Skeletal Assemblage}

A total of 21 simple pit burials containing 46 individuals were excavated from the Grand Plaza cemetery (Table 4). The bodies were laid supine in an east or west orientation with arms generally folded across the chest or abdomen, and some individuals had their legs crossed at the ankles. Bone beads were found in one burial, but no other clearly associated grave goods were encountered in the Grand Plaza burials (but see note for burials 21 and 26 in Table 4). Fourteen of the 21 burials contained more than one individual, with a maximum of five individuals in a single grave. In seven graves $(3,5,6$, $9,18,19,31)$, the bodies were stacked in an alternating head-to-foot orientation. Stratigraphic analysis indicates that each grave represents a single burial deposit.

Amorphous calcium carbonate deposits (possibly precipitated from calcium hydroxide or slaked lime) were observed in several burials, most notably in burial 21 , in which a thick layer was observed directly above a hollow cavity contain- 
Table 3. Comparative Collagen Carbon and Nitrogen Isotopic Values from Prehispanic Populations in the State of Oaxaca, Mexico.

\begin{tabular}{lccccc}
\hline Site & Culture & $\begin{array}{c}\text { Collagen } \\
\delta^{13} \mathrm{C}(\mathrm{VPDB})\end{array}$ & $\begin{array}{c}\text { Collagen } \\
\delta^{15} \mathrm{~N}(\mathrm{AIR})\end{array}$ & $\mathrm{C} / \mathrm{N}^{\mathrm{a}}$ & Reference \\
\hline El Paragüito & Zapotec & -7.5 & 8.8 & 3.0 & This study \\
El Paragüito & Zapotec & -7.8 & 8.5 & 2.9 & This study \\
Lambityeco & Zapotec & -7.9 & 8.9 & 2.8 & This study \\
Monte Albán & Zapotec & -6.4 & 9.2 & 2.9 & This study \\
Monte Albán & Zapotec & -7.4 & 10.0 & 2.8 & Blitz 1995 \\
Monte Albán & Zapotec & -7.2 & 9.7 & 2.8 & Blitz 1995 \\
Monte Albán & Zapotec & -9.1 & 10.5 & 2.8 & Blitz 1995 \\
Monte Albán & Zapotec & -8.1 & 10.5 & 3.1 & Blitz 1995 \\
Monte Albán & Zapotec & -8.4 & 9.0 & 2.7 & Blitz 1995 \\
Monte Albán & Zapotec & -10.1 & 7.2 & 2.4 & Blitz 1995 \\
Monte Albán & Zapotec & -8.3 & 9.3 & 2.6 & Blitz 1995 \\
Monte Albán & Zapotec & -7.7 & 10.3 & 2.9 & Blitz 1995 \\
Monte Albán & Zapotec & -9.0 & 9.3 & 2.9 & Blitz 1995 \\
Monte Albán & Zapotec & -7.4 & 9.8 & 2.9 & Blitz 1995 \\
San Miguel Albarradas & Zapotec & -6.9 & 6.5 & 2.9 & This study \\
San Pedro Ixtlahuaca & Zapotec & -7.7 & 8.5 & 2.9 & This study \\
Xatachio & Zapotec & -8.0 & 10.7 & 2.9 & This study \\
\hline
\end{tabular}

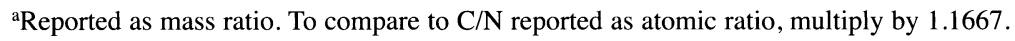

ing the skeletal remains. The use of lime, possibly to reduce putrefaction odors, has also been observed in burials at the colonial mission of St. Augustine in La Florida (Koch 1983). A fragment of leather and thin scales of textile impressions were preserved underneath some of these deposits. It is unknown if the textile impressions indicate the use of burial shrouds (mortajas), which were used during the sixteenth century to wrap the bodies of the dead in both Spain (Eire 1995; Foster 1960) and New Spain. Preliminary analysis identified at least two weave patterns among the fragments: a basket weave associated with individual 39 and a twill weave associated with individual 40 (Warinner 2010).

The burials within the Grand Plaza were laid out in an orderly fashion according to what appears to be a gridded plan. The burials were cut directly into the plaster surface of the plaza, which was not repaired or replastered after interment. Unlike at other early colonial cemeteries where old graves were frequently partially disinterred to make room for the new (e.g., at Huexotla, Tipu, and Santa Catalina de Guale; see references in Table 5), there is little evidence for grave disturbance in the Grand Plaza, and only two neighboring graves (burials 1 and 2) in the center of the plaza display evidence of human disturbance subsequent to burial.
Thirty-seven individuals could be assigned sex on the basis of pelvic and cranial features. The sex distribution is slightly biased toward females, who make up 59 percent of the adults whose sex could be determined. The number of infants $(0)$, children under 12 (1), and adults 45 and older (6) is noticeably low, and there is a relatively large number of adolescents and young adults with partially or recently erupted third molars (26) compared with middle-aged adults between the ages of 25-34 (6) and 35-44 (7).

\section{Churchyard Skeletal Assemblage}

Seven burials containing eight individuals were excavated from three small test pits in the churchyard (Table 4). As in the Grand Plaza cemetery, individuals were buried in an extended supine position with the arms folded across the chest or abdomen or lying at the sides. Unlike in the Grand Plaza cemetery, however, the burials were oriented to the north or south along the same axis as the colonial church and contained only one individual each. The only exception was the burial of an adult male and an approximately two-year-old child.

Five individuals from the churchyard could be assigned sex on the basis of pelvic and cranial features: four females and one male. Notably, three of the eight individuals excavated from the church- 


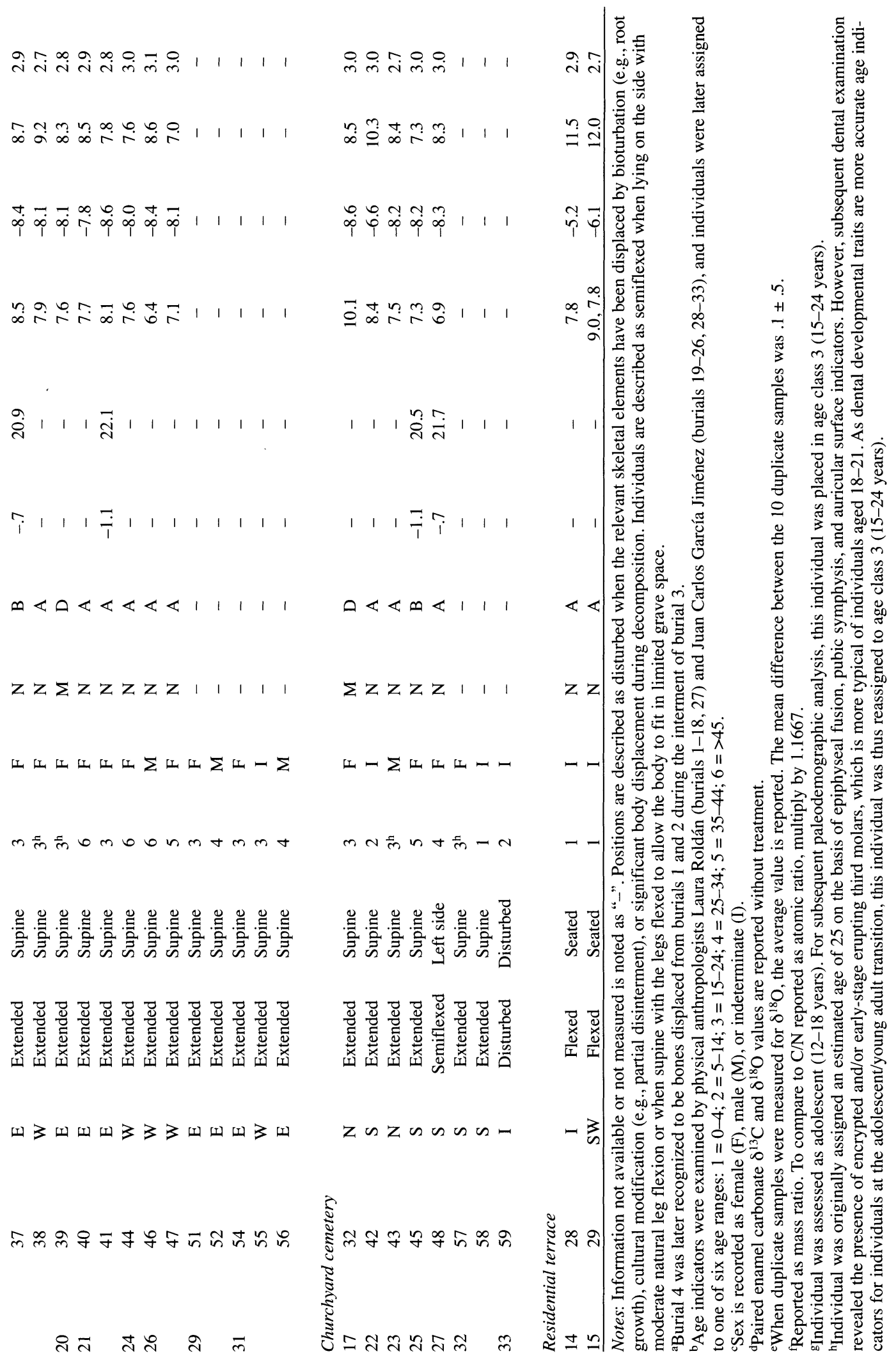


Table 5. Published Reports of Excavated Sixteenth-Century Cemeteries in New Spain.

\begin{tabular}{|c|c|c|c|}
\hline Cemetery & Dates of Use & $\mathrm{N}$ & References \\
\hline \multicolumn{4}{|l|}{ Central Mexico } \\
\hline Convento de San Gabriel (Cholula) & ca. $1519^{a}$ & 671 & $\begin{array}{l}\text { Castro Morales and García Moll 1972; } \\
\text { McCafferty 2000; Ocaña del Río } 1985\end{array}$ \\
\hline Huexotla/Chapingo & ca. $1524-1600$ & 60 & $\begin{array}{l}\text { Malvido and Viesca 1985; Malvido et al. 1986; } \\
\text { Mansilla and Pompa } 1992\end{array}$ \\
\hline San Sebastian Molango & ca. $1550-1600$ & 71 & Charlton et al. 2005 \\
\hline San Jeronimo & 16th-19th centuries & 147 & $\begin{array}{l}\text { Mansilla et al. 1992; Romano Pacheco and } \\
\text { Jaén Esquivel } 1985\end{array}$ \\
\hline \multicolumn{4}{|l|}{ Oaxaca } \\
\hline $\begin{array}{l}\text { Teposcolula Yucundaa } \\
\text { Yucatán Peninsula }\end{array}$ & ca. $1538-1552$ & 46 & Spores and Robles García 2007 \\
\hline Campeche & 16th-17th centuries & 122 & Tiesler and Zabala 2010 \\
\hline Tancah & ca. $1543-1688$ & 20 & Miller and Farriss 1979 \\
\hline Lamanai & ca. $1544-1641$ & 179 & $\begin{array}{l}\text { Graham et al. 1989; Pendergast 1991; } \\
\text { White et al. } 1994\end{array}$ \\
\hline Tipu & ca. $1567-1638$ & $>550$ & $\begin{array}{l}\text { Cohen et al. 1994; Danforth et al. 1997; } \\
\text { Jacobi } 2000\end{array}$ \\
\hline \multicolumn{4}{|r|}{ 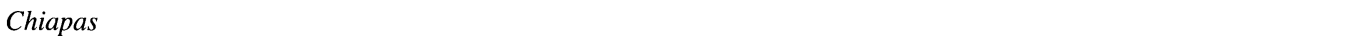 } \\
\hline Coapa & ca. $1554-1680$ & 84 & Lee 1979 \\
\hline \multicolumn{4}{|l|}{ La Florida ${ }^{b}$} \\
\hline San Juan del Puerto & ca. $1587-1702$ & 5 & Dickinson 1989; Larsen 1993 \\
\hline Nuestra Señora de Soledad (St. Augustine) & ca. $1597-1784$ & 28 & Koch 1983 \\
\hline Santa Catalina de Guale & ca. $1597-1680$ & 432 & Larsen 1993, 1990; Larsen et al. 1990 \\
\hline
\end{tabular}

Notes: Includes only individuals excavated from primary contexts.

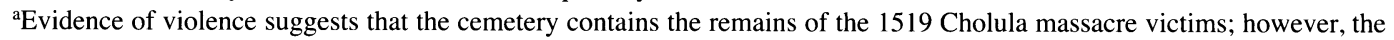
cemetery may also contain individuals interred at a later date.

${ }^{\mathrm{b}} \mathrm{A}$ wealth of bioarchaeological data have been produced for colonial cemeteries in La Florida; however, most excavated La Florida cemeteries date to the seventeenth and eighteenth centuries, a time period outside the scope of this article. See

Larsen 1993 for more information about these cemeteries.

yard were age five or younger. Six of the seven graves contained no grave goods. One grave, burial 27, located in the center of the churchyard, contained an exceptional number of grave goods (figurines, pendants, and beads numbering in the tens of thousands) and is presumed to be a Postclassic royal burial (Warinner 2010).

\section{Residential Terrace Skeletal Assemblage}

Two infants under the age of three were recovered from two simple pit burials in outlying commoner residential terraces. The infants were placed in a flexed, seated position, and each was accompanied by a shallow ceramic dish (cajete) of the Postclassic Yanhuitlan Fine Cream type.

\section{Teposcolula Grand Plaza and Churchyard Skeletal Assemblages in Context}

Prior to the arrival of Spanish missionaries, Mixtecs typically buried their dead in simple pit burials, stone-lined crypts, or family tombs located in residential compounds. Grave goods such as ceramic vessels were frequently, but not always, included. The bodies of adults were usually laid out in an extended supine position, with arms placed at the sides (Acosta 1992; Blomster 2004; Gaxiola González 1984; Robles García 1988); however, Postclassic carved stone figurines at Teposcolula also depict the dead with arms folded across the body (Warinner 2010).

Both Postclassic and colonial burials at Teposcolula Yucundaa are characterized by a general absence of grave goods, a high incidence of extended supine body positioning ( 76 percent), and a predominance of arm-folding across the chest or abdomen (81 percent) - a mortuary pattern that overlaps with contemporary Spanish Catholic practices (Eire 1995; Koch 1983; Rush 1941). In the Grand Plaza, the lack of a consistent body orientation and the mass burial of individuals within an extramural cemetery, however, differ from contemporary colonial Spanish practices. 
In sixteenth-century Spain, most Catholics were buried within churches or chapels, or, at the very least, within consecrated walled churchyard cemeteries (Eire 1995:94; Foster 1960). Excavated early colonial cemeteries in New Spain (Table 5) conform to this pattern, with a high density of burials within and immediately surrounding the church (Malvido 1997). By contrast, colonial burials at Teposcolula Yucundaa were found exclusively in the Grand Plaza, an area otherwise associated with Mixtec civic-ceremonial functions (Spores and Robles García 2007). No burials or evidence of repaired rompimientos (burial cuts) were encountered within the Teposcolula Yucundaa church, and graves encountered within the walled churchyard were found by direct radiocarbon dating to predate the colonial period (Table 1). The unusual mortuary features encountered in the Teposcolula Yucundaa Grand Plaza offer few clear insights into the biological or cultural affiliations of the interred individuals, thus necessitating alternative lines of evidence, such as ancient DNA mitochondrial haplogroup testing and stable isotope-based paleomigration and paleodietary analysis.

\section{Oxygen Isotopic and Genetic Analysis of the Teposcolula Skeletal Assemblages}

Stable isotope analysis and mitochondrial haplogroup testing were employed to determine genetic affinity, assess population homogeneity, and characterize the geographic origin of individuals within the Teposcolula burial assemblages. Recent investigations in Campeche have revealed the presence of multiple ethnic groups buried within a single early colonial cemetery (Tiesler and Zabala 2010), raising the possibility that a similar pattern might be found in the rapidly developing colonial town of Teposcolula Yucundaa.

During the early colonial period, there is historical evidence for the presence of several different groups in the Mixteca Alta region that may have been present at Teposcolula in the sixteenth century, including local Mixtecs, central Mexicans, slaves of West African or Caribbean descent, and Spanish missionaries, officials, and settlers. Slaves were first brought to the region in the 1520 s by Teposcolula's second encomendero, Juan Pelaez de Berrio, to pan for gold (Chance 1978). Throughout the 1540 s at least one and as many as six
Dominican friars lived in residence at Teposcolula at any given time (Vences Vidal 2000), and excavations of the Teposcolula monastery in 2005 identified at least seven small rooms that may have served as cells for resident or traveling friars (Robles García and Spores 2005; Spores and Robles García 2007). Historical records indicate that nonecclesiastical Spanish settlers also began moving to the Mixteca Alta in the late 1530s and early 1540s (Romero Frizzi 1990), but it is not known if any of these Spaniards lived at Teposcolula.

\section{Oxygen Stable Isotopes of the Teposcolula Burials}

Oxygen isotopic values of mineralized tissues have been shown to correlate with precipitation and temperature gradients (Longinelli 1984; Luz and Kolodny 1989), and thus oxygen isotopic analysis can be used to investigate archaeological histories of human migration across diverse ecological zones (e.g.,Price et al. 2010; Quinn et al. 2008; Schroeder et al. 2009). Oxygen isotopes in both organic and inorganic substrates (collagen and enamel carbonate) were measured in order to assess whether the Teposcolula Grand Plaza cemetery represents a local Mixtec population or if there is evidence for nonlocal migrants at the site (Table 4).

The average $\delta^{18} \mathrm{O}_{\text {bone collagen }}$ in the colonial Grand Plaza cemetery $(8.4 \pm .7 \%$ ) compares closely with that in the Postclassic churchyard burials $(8.2 \pm$ $1.4 \%$ ), as well as with two Postclassic low-status infant burials recovered from outlying residential terraces at Teposcolula $(7.8 \%$, 8.4\%o), suggesting that the individuals interred in the Grand Plaza are of local origin (Table 4). A comparison of Grand Plaza cemetery $\delta^{18} \mathrm{O}_{\text {enamel carbonate }}$ with that measured for individuals from a variety of other sites also supports the interpretation that the cemetery does not contain long-distance migrants from Spain, Africa, the Caribbean, or other parts of Mesoamerica (Figure 3; comparative data from Bell et al. 2006; Price et al. 2010; Schroeder et al. 2009; White et al. 2000; and Wright and Schwarcz 1998). The relatively depleted $\delta^{18} \mathrm{O}_{\text {enamel carbonate }}$ observed for all three Teposcolula burial assemblages is consistent with the relatively cool and wet climate characteristic of the Mixteca Alta, especially compared with that of southern Spain and the other Mesoamerican and Caribbean regions that have been analyzed. 


\author{
Southern Spain $+t(n=2)$ \\ Barbados, African $\div(n=9)$ \\ Postclassic Teposcolula $(n=2)$ \\ Colonial Teposcolula $(n=14)$ \\ Kaminaljuyu $(\mathrm{n}=24)$ \\ Copan $\nleftarrow(n=10)$
}

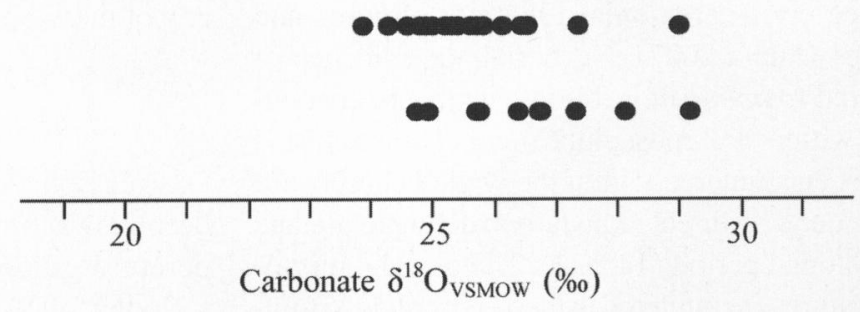

Figure 3. Enamel carbonate oxygen isotopic values. Human enamel measurements are from third molars only. $\dagger$ Data from modern horse enamel; no human enamel from Holocene Spain has been analyzed for carbonate $\delta^{18} O$. $\ddagger$ Original $\delta^{18} O$ measured relative to VPDB; to approximate $\delta^{18} O$ on the VSMOW scale, the following transformation was performed: $\delta^{18}$ OVSMOW $=1.03086 * \delta^{18} O V P D B+30.86$ (Friedman and O'Neil 1977; Werner and Brand 2001).

\section{Genetic Analysis}

Ancient DNA Analysis of the Teposcolula Burial Assemblages. Forty-one individuals from the Teposcolula Grand Plaza cemetery were tested for mitochondrial ancestry informative markers characteristic of the two major macrohaplogroups found outside of Africa, $\mathrm{M}$ and $\mathrm{N}$, and the four major indigenous American haplogroups, A, B, C, and D (Table 4). Seven additional Postclassic skeletons from the churchyard and outlying residential terraces were also analyzed for comparison. All 48 individuals could be assigned to both macrohaplogroup and haplogroup, and no individuals exhibited ancestry informative markers consistent with more than one haplogroup. All individuals were found to belong to macrohap$\operatorname{logroups} \mathrm{M}$ or $\mathrm{N}$, thus indicating that there are no individuals of maternal African descent in the skeletal assemblage. Further haplogroup testing of the assemblage demonstrated that all individuals exhibit markers consistent with haplogroups A, $\mathrm{B}, \mathrm{C}$, or D, indicating that there are no Europeans in the assemblage and confirming that all tested individuals are of indigenous American ancestry. This agrees with the results of the oxygen stable isotope analysis, which found no evidence for foreign-raised individuals in the cemeteries.

\section{Ancient and Modern Mitochondrial Haplogroup} Frequencies of Indigenous Populations.

Genetic studies of modern indigenous American populations have revealed continental and regional patterning in mitochondrial haplogroup frequency distributions (Malhi et al. 2002; Schurr 2004; Torroni et al. 1992; Torroni et al. 1993). The haplogroup frequency distribution of the Grand Plaza skeletal assemblage (Table 6) is typical of a Mesoamerican population, which is generally characterized by a high frequency of haplogroup $\mathrm{A}$, and is distinct from the dominant $\mathrm{C}$ and $\mathrm{D}$ haplogroup pattern observed among the ancient Taino and Carib populations of the Caribbean $\left(p<.001, \chi^{2}\right.$ test for homogeneity). Within Mesoamerica, the haplogroup frequency distribution of the colonial Teposcolula Grand Plaza assemblage compares closely with that of modern Mixtecs $\left(p>.1, \chi^{2}\right.$ test for homogeneity; Table 6). The haplogroup frequency profile of the Grand Plaza assemblage indicates long-term genetic continuity in the Mixteca Alta and further supports the characterization of the Grand Plaza cemetery as containing a local, Mixtec population. 
Table 6. Mitochondrial Haplogroup Frequencies of Colonial Teposcolula and Other Modern and Ancient Mesoamerican and Caribbean Populations.

\begin{tabular}{|c|c|c|c|c|c|c|c|}
\hline \multirow[b]{2}{*}{ Population } & \multirow[b]{2}{*}{$\mathrm{N}$} & \multicolumn{5}{|c|}{ Haplogroup Frequency (\%) } & \multirow[b]{2}{*}{ Reference(s) } \\
\hline & & $\mathrm{A}$ & $\mathrm{B}$ & $\mathrm{C}$ & $\mathrm{D}$ & $\mathrm{X}$ & \\
\hline \multicolumn{8}{|l|}{ Mesoamerica } \\
\hline Colonial Mixtec $^{\mathrm{a}}$ & 41 & 54 & 24 & 17 & 5 & 0 & This study \\
\hline Modern Mixtec & 123 & 67 & 23 & 7 & 3 & 0 & $4,6,9,12,15$ \\
\hline Modern Zapotec & 100 & 41 & 24 & 30 & 5 & 0 & $4,6,9,15$ \\
\hline Modern Mixe & 68 & 38 & 29 & 24 & 9 & 0 & $4,6,9,15$ \\
\hline Ancient Nahua & 37 & 62 & 16 & 5 & 10 & 0 & 2,5 \\
\hline Modern Nahua & 404 & 56 & 29 & 8 & 6 & 0 & $4,6,9,10,11,12$ \\
\hline Ancient Maya (Xcaret)* & 24 & 88 & 4 & 8 & 0 & $\mathrm{~b}$ & 3 \\
\hline Modern Maya & 91 & 59 & 23 & 11 & 7 & 0 & $1,12,13,14$ \\
\hline \multicolumn{8}{|l|}{ Caribbean } \\
\hline Ancient Taino** & 24 & 0 & 0 & 75 & 25 & $\mathrm{~b}$ & 8 \\
\hline Ancient Ciboney** & 15 & 7 & 0 & 60 & 33 & 0 & 7 \\
\hline
\end{tabular}

Note: Includes only populations with a sample size of at least 10 . Excludes individuals with haplogroups indicative of European or African admixture, as well as individuals for whom haplogroup assignment was not determined. $1=$ Boles et al. 1995; 2 = De la Cruz et al. 2008; $3=$ González-Oliver et al. 2001; $4=$ Kemp 2006; $5=$ Kemp et al. 2005; $6=$ Kemp et al. 2010; 7 = Lalueza Fox et al. 2001; 8 = Lalueza Fox et al. 2003; $9=$ LeBlanc et al. 2007; $10=$ Lorenz and Smith 1996; $11=$ Malhi et al. 2003; 12 = Peñaloza-Espinosa et al. 2007; $13=$ Smith et al. 1999; $14=$ Torroni et al. 1992; $15=$ Torroni et al. 1994.

${ }^{a}$ Teposcolula Grand Plaza burials.

${ }^{b}$ Testing for haplogroup $\mathrm{X}$ was not performed, and the haplogroup assignment of at least one individual from this population is given as "other" (i.e., not A, B, C, or D).

*Haplogroup frequency significantly different from Teposcolula at .05 level using $\chi 2$ test for homogeneity.

**Haplogroup frequency significantly different from Teposcolula at .01 level using $\chi^{2}$ test for homogeneity.

\section{Evidence for a Catastrophic Event}

Soren (2003) has outlined several characteristics typical of so-called abnormal, or catastrophic, cemeteries, including (1) evidence of mass burial or multiple individuals within a single grave; (2) rapid, successive vertical depositions; (3) installment in a single layer at one time or in a large cluster; and (4) corroborating historical evidence. The Teposcolula Grand Plaza cemetery meets each of these mortuary criteria, and there is additionally good historical evidence for a major epidemic in the Mixteca Alta at this time.

\section{Mortuary Evidence}

Two-thirds of the burials within the Grand Plaza contain more than one individual, with as many as five bodies within a single grave. In approximately half of the graves with multiple individuals, bodies were vertically stacked in alternating directions, perhaps as a space-saving measure. This differs from practices at other colonial cemeteries, where a single burial orientation predominates at fre- quencies over 90 percent (e.g., Cohen et al. 1994; Larsen 1993; Malvido and Viesca 1985; Ocaña del Río 1985). The rigidly geometric layout of the Grand Plaza cemetery also suggests a large-scale, coordinated burial effort over a short period of time, as opposed to the more loosely organized and overlapping burial patterns typically observed at attritional colonial cemeteries (e.g., Cohen et al. 1994; Koch 1983; Malvido et al. 1986).

Finally, the identification of a large indigenous colonial cemetery not associated with a church or churchyard is highly unusual and has not been previously documented. Excavated early colonial cemeteries in New Spain are typically characterized by a high density of burials within and immediately surrounding a church, and in this respect the extramural Grand Plaza cemetery is clearly anomalous.

\section{Historical Evidence}

In late 1544, an unidentified epidemic broke out in New Spain. The Codex Telleriano-Remensis represents the "great mortality" with stacks of corpses, 

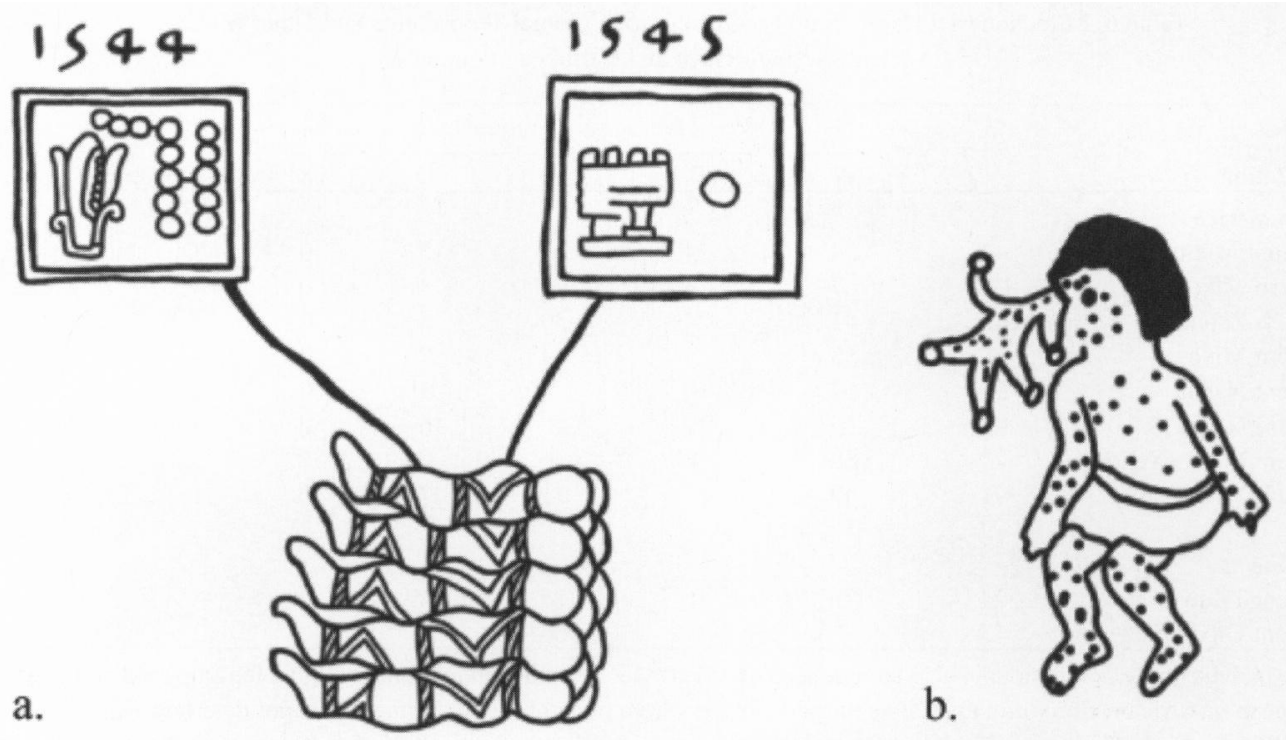

Figure 4. Depictions of the 1545-1550 epidemic in native documents: (a) Codex Telleriano-Remensis, folio 46v; and (b) Codex en Cruz (drawings by the author).

and the Codex en Cruz depicts the two most common symptoms of the epidemic: severe nosebleeds and a body rash (Figure 4). Although the nature of the epidemic is poorly understood, historical sources agree that it was devastating, with an estimated mortality rate of 60-90 percent (Cook 1998; de Mendieta 1945; de Sahagún 1956; Motolinía 1971; Prem 1992). Witnesses, both Spanish and native, had never seen anything like it before and had no name to describe it, calling it instead pujamiento de sangre (abundant bleeding or full bloodiness) in Spanish and huey cocoliztli (great pestilence) in Nahuatl (Cook 1998; Prem 1992). It is one of three sixteenth-century epidemics that can be described as a true pandemic, which spread from central Mexico to Guatemala and beyond (possibly to Peru), eventually infecting all of New Spain and perhaps lingering in Guatemala until 1563 (Lovell 1992; Newson 1992; Prem 1992).

Located along the principal trade routes between Mexico and Guatemala, the people of the Mixteca Alta became infected as well. A document from 1545 records that at the Mixtec community of Coixtlahuaca (located approximately $30 \mathrm{~km}$ to the northeast of Teposcolula), burial could not keep pace with the 30-40 people who were dying each day during the epidemic (Terraciano 2001), and Teposcolula's own resident Friar Bernardino de Santa María is recorded to have fallen ill at this time
(Jiménez Moreno and Mateos Higuera 1940; Warinner 2010). Thirty years later, four other neighboring Mixtec communities remembered the 1545-1548 "pestilence" as the only epidemic to reach the Mixteca Alta between the early 1530 s and 1577 (Acuña 1984; records for Teposcolula have been lost, see discussion in Warinner 2010). The cause of the great pestilence of 1545 is unknown but may have been epidemic typhus (Fields 2008; Humboldt 1811; Zinsser 1934), pneumonic plague (MacLeod 1973; Malvido and Viesca 1985; Orellana 1987), or a viral hemorrhagic fever (Acuña Soto et al. 2000; Acuña Soto et al. 2002; Marr and Kiracofe 2000).

\section{Paleodemography}

In addition to mortuary and historical evidence, the paleodemographic profile of the Teposcolula Grand Plaza cemetery also conforms to a catastrophic, rather than attritional, pattern (Figure 5). A sharp rise in mortality among adolescents and young adults, as seen during the 1918 influenza pandemic and in the Teposcolula Grand Plaza cemetery, is characteristic of a catastrophic event. Although straightforward comparison of mortality profiles obtained from diverse data sets is made problematic by "age-heaping" in historical data (see Chamberlain 2006) and statistical biases in age determination from osteological data (see Hoppa 


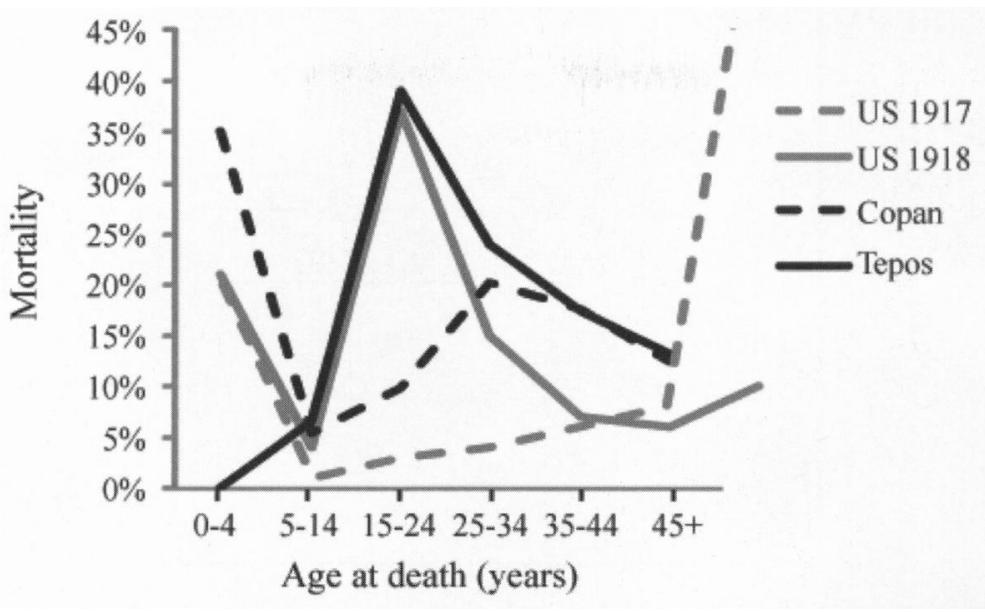

Figure 5. Comparison of attritional and catastrophic mortality profiles derived from historic and archaeological data. Gray lines signify the mortality (percent of deaths from lung infection) of a subset of the U.S. population before (dashed) and during (solid) the 1918 influenza pandemic. Black lines signify mortality (percent of excavated) in an attritional skeletal assemblage from Copán, Honduras (dashed) and the Teposcolula Grand Plaza (solid).

and Vaupel 2002), attritional and catastrophic patterns can nevertheless be discerned from both historical and bioarchaeological data (e.g., Gowland and Chamberlain 2005; Signoli 2006).

The Teposcolula Grand Plaza cemetery is characterized by a very high frequency of adolescents and young adults aged 15-24, an ordinarily healthy age group usually making up a relatively small proportion of attritional cemeteries (e.g., Hollingsworth and Hollingsworth 1971; Whittington 1989). Excessively high mortality of adolescents and young adults is a typical feature of catastrophic epidemics and has been historically documented for plague outbreaks in medieval and early modern Europe (Hollingsworth and Hollingsworth 1971; Signoli et al. 2002), as well as the 1918 influenza pandemic in the United States (Crosby 1976). Bioarchaeological evidence from European plague cemeteries shows a similar trend, although long-term alterations in the underlying age profile caused by centuries of serial epidemics have made medieval European patterns more complex and, thus, not directly comparable (DeWitte and Wood 2008; Gowland and Chamberlain 2005; Margerison and Knüsel 2002; Signoli 2006; Signoli et al. 2002; Waldron 2001; see Warinner 2010 for discussion).

The mortality profile of adolescents and young adults at Teposcolula differs markedly from that observed at the well-studied prehispanic Mesoamer- ican site of Copán (ca. A.D. 400-900), which is thought to be an attritional skeletal assemblage (Whittington 1989). The unusually high proportion of individuals aged 15-24 compared with those over 25 , however, may also reflect additional biological and social factors, including earlier population losses from previous epidemics and interment bias reflecting differences in baptismal rates among age groups (Warinner 2010). The complete lack of children under the age of seven in the Grand Plaza assemblage is unusual and suggests that infants and young children either died early in the epidemic (before the establishment of the Grand Plaza cemetery), were systematically buried elsewhere, or received treatment that did not include burial.

\section{Colonial Consequences}

\section{Demographic Impact}

The demographic impact of epidemic disease on Teposcolula is difficult to reconstruct with any precision. On the basis of settlement survey data, Stiver (2001) estimates that the population of Teposcolula and its immediate hinterlands numbered between 20,000 and 44,500 people at Spanish contact. By contrast, a colonial census conducted just after the 1545-1548 epidemic (ca. 1548-1550) at Teposcolula records 2,934 households and 9,386 people over the age of three (Paso y Troncoso 

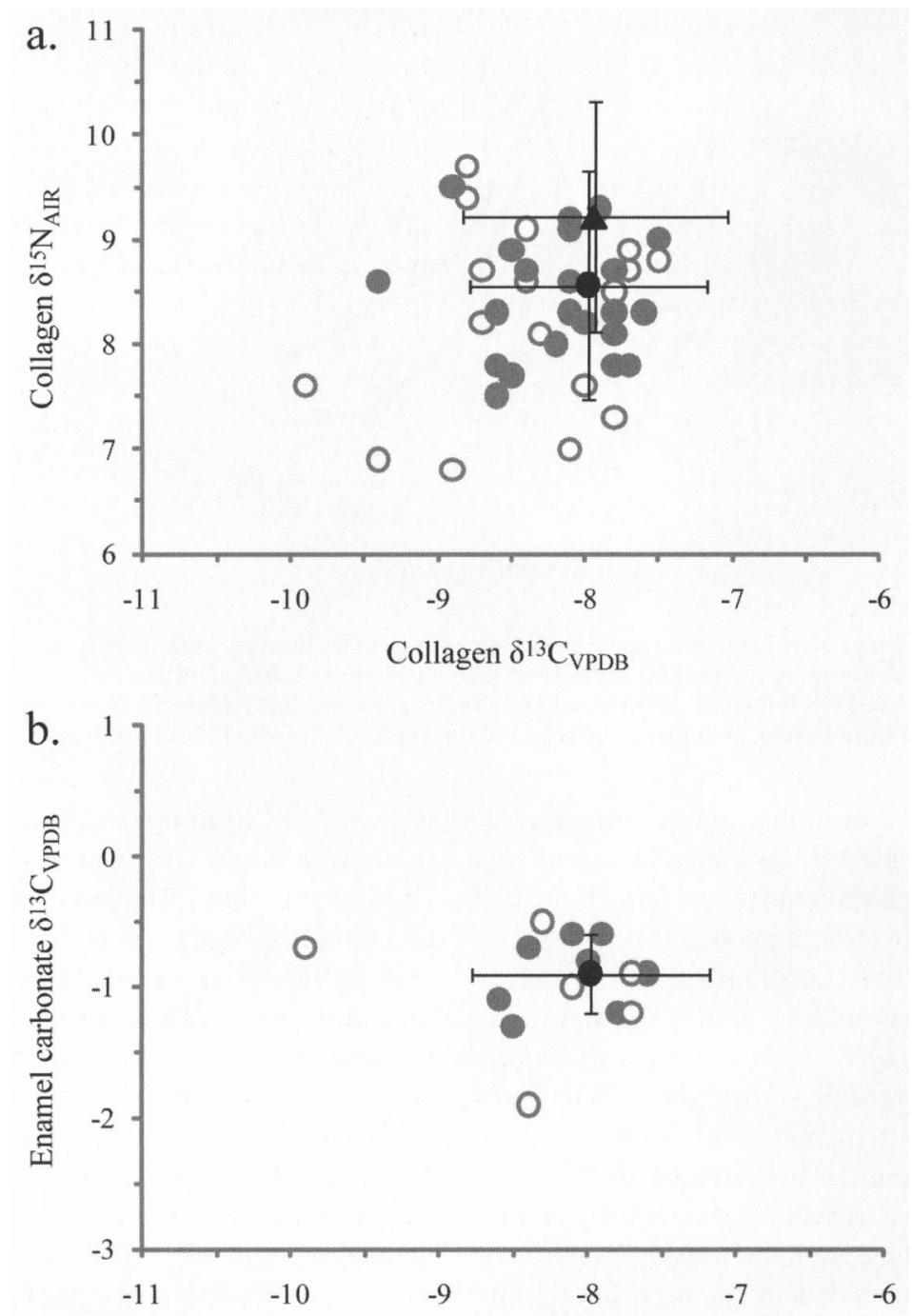

Collagen $\delta^{13} \mathrm{C}_{\mathrm{VPDB}}$

Figure 6. Distribution of bone collagen and enamel carbonate isotopic values from individuals aged 5-24 (*) and age 25 and older ( ) in the Teposcolula Grand Plaza compared with Postclassic burials at Teposcolula $(\bullet)$ and other prehispanic populations in the Valley of Oaxaca $(\Delta)$. Error bars represent \pm 1 SD.

1981). This dramatic difference may reflect substantial mortality and population decline during the epidemic or may result from differences in the delineation of territorial boundaries and methods used to arrive at population estimates. Although historical documents are inconclusive regarding the impact of early epidemics at Teposcolula, census records from 1570 to 1650 indicate that the population of the Teposcolula jurisdiction fell from 26,500 to 14,100 after the epidemics of 1576-1581, 1591-1592, and 1599 and reached a low point of
6,522 in 1646, a population decline of over 75 percent in less than a hundred years (Cook and Borah 1968; Gerhard 1993).

\section{Economic Change}

Alongside population decline, the Mixteca Alta also experienced rapid economic change during the early colonial period (Riquer 1990; Romero Frizzi 1990). Many Spanish agricultural species were introduced to New Spain at this time, including wheat, which Teposcolulans were required to 
grow from 1531 to 1563 to satisfy royal tax obligations (Pérez Ortiz 2003; Spores 1967). Historical references to wheat cultivation during this period appear primarily in connection with the provisioning of Spanish cities and monasteries (Cuevas 1975; Terraciano 2001), but it is not known when or to what degree wheat was consumed by indigenous populations during the early colonial period.

Pellicer (1990) has argued that wheat, in addition to being grown for taxation, may have also become an important fallback grain for some indigenous populations. The Mediterranean variety of wheat introduced by the Spanish was relatively frost resistant and required less water than maize (Riquer 1990) and was thus more suited to the cool climate of the Mixteca Alta, where variable frost dates and rainfall frequently led to maize crop damage or failure at communities such as Teposcolula (de la Peña 1950; Riquer 1990). With a shrinking labor supply, agricultural stability would have become increasingly important. In order to determine the importance of wheat consumption in indigenous diets at Teposcolula, carbon stable isotope values were measured from bone collagen and enamel apatite samples from individuals in the Grand Plaza cemetery (Table 4).

\section{Carbon Stable Isotope Analysis of the Teposcolula Skeletal Assemblages}

Stable isotope analysis of the Teposcolula Yucundaa skeletal assemblage supports continuity in maize consumption and an absence of significant wheat consumption during the early colonial period. If wheat consumption had correlated with historically documented wheat cultivation at Teposcolula, $\delta^{13} \mathrm{C}$ values of collagen and enamel would be expected to be lower in the colonial Grand Plaza burials compared with the Postclassic churchyard and other prehispanic burials in the region. However, the high collagen $\delta^{13} \mathrm{C}$ values of the Grand Plaza skeletal assemblage are instead consistent with a diet rich in C4 and CAM plant resources, such as maize, amaranth, agave, and cactus fruit (Warinner et al. 2012), and the collagen isotopic distribution of the Grand Plaza assemblage closely resembles that measured for prehispanic burials at Teposcolula and other sites in the Valley of Oaxaca (Figure 6a and Table 3). Furthermore, when broken down by age group, collagen $\delta^{13} \mathrm{C}$ values for adults age 25 and older in the Grand Plaza are not significantly different from those of individuals aged 10-24, who grew up almost entirely during the period of wheat cultivation at Teposcolula ( $p>.1$, ANOVA).

The $\delta^{13} \mathrm{C}$ values of third molar enamel apatite also indicate dietary continuity before and after the introduction of wheat (Figure $6 \mathrm{~b}$ ). The enamel of individuals aged 18-24 formed between approximately 1534 and 1545 , the period of wheat cultivation at Teposcolula, while individuals 25 and older formed their third molar enamel between approximately 1505 and 1533 , the period predominantly before wheat introduction at Teposcolula. A comparison of third molar enamel apatite $\delta^{13} \mathrm{C}$ values between individuals aged $18-24$ and individuals 25 and older reveals no significant carbon isotopic differences between the two age groups ( $p>.1$,ANOVA) and no isotopic difference from Postclassic values.

Thus, although minor consumption of wheat cannot be ruled out, carbon isotope analysis of bone collagen and enamel apatite indicates no evidence of a substantial shift toward wheat consumption in early colonial Teposcolula, suggesting that wheat was grown almost exclusively as a cash or tribute crop. The fact that maize continued to be the dominant staple food crop in colonial Mixtec diets, despite the practical advantages offered by a frostresistant and drought-tolerant variety of wheat, attests to the persistent centrality and symbolic importance of maize in colonial Mixtec culture and identity.

\section{Conclusions}

Excavations at the site of Pueblo Viejo Teposcolula have yielded important insights into early colonial life at a Mixtec community undergoing rapid demographic and socioeconomic change. Mortuary and paleodemographic analysis of the Grand Plaza cemetery, the first clearly epidemic-associated sixteenth-century cemetery to be excavated in Mexico, substantiates the catastrophic mortality of the historically documented early colonial epidemics, and bone specimens collected from the cemetery provide valuable biological samples for future ancient genetic testing of the cause of this poorly understood epidemic.

Mitochondrial haplogroup typing confirms the indigenous American ancestry of the dead in Grand 
Plaza cemetery, and the haplogroup frequency profile of the assemblage closely resembles that of modern Mixtecs, indicating long-term genetic continuity in the region. Oxygen isotope analysis indicates that the Teposcolula Grand Plaza cemetery is composed of a local population, and carbon and nitrogen isotope analysis supports a continued dietary reliance on $\mathrm{C} 4$ and CAM crops, such as maize and agave, during the early colonial period, despite historical evidence for increased wheat production at the site.

The application of an integrated bioarchaeological approach, including mortuary, paleodemographic, ancient DNA, and stable isotope analysis, has yielded important insights into early colonial life at Teposcolula Yucundaa. By bringing together multiple lines of evidence, we find both support for and divergence from conventional models of colonial social and biological change. Catastrophic population loss does seem to have been a key factor in the effective institution of congregación, but other changes attested in historical records and material culture may have been more superficial. Rather than illustrating rapid change, biological evidence relating to ancestry, migration, and subsistence paints a picture of continuity and resilience across the colonial transition, despite population losses. The Teposcolula Grand Plaza cemetery provides a rich and complex perspective on early colonial life in the Mixteca Alta and reaffirms the importance of archaeological and bioarchaeological evidence in investigating complex social and biological processes of the past.

Acknowledgments. This research was conducted under permit 401-3-5113 issued by the Instituto Nacional de Antropología e Historia de México and was supported by grants from the David Rockefeller Center for Latin American Studies, the Harvard University Owens Fund, and the Harvard University Graduate Student Council. We would like to thank the entire Proyecto Arqueológico Pueblo Viejo Teposcolula Yucundaa archaeological team, especially Laura Diego and Laura Roldán, as well as William Fash and Davíd Carrasco, who provided helpful comments on early drafts of this article.

\section{References Cited}

Acosta, Jorge R.

1992 Tipo físico. In Exploraciones en Monte Negro, Oa$x a c a$, edited by Jorge R. Acosta and Javier Romero, pp. 137-153. Antologías, Serie Arqueología. Instituto Nacional de Antropología e Historia, Mexico City.
Acuña, René

1984 Relaciones geográficas del siglo XVI, Vols. 2-3. Universidad Nacional Autónoma de México, Mexico City.

Acuña-Soto, Rodolfo, Leticia Calderón Romero, and James H. Maguire

2000 Large Epidemics of Hemorrhagic Fevers in Mexico 1545-1815. American Journal of Tropical Medicine 62(6):733-739.

Acuña-Soto, Rodolfo, David W. Stahle, Malcolm K. Cleaveland, and Matthew D. Therrell

2002 Megadrought and Megadeath in 16th Century Mexico. Emerging Infectious Diseases 8:360-362.

Alavez, Raúl

1988 Toponimia mixteca. Centro de Investigaciones y Estudios Superiores en Antropología Social, Mexico City.

Alavez Chávez, Raúl Gabriel

2006 Toponimia mixteca II: Mixteca Alta, comunidades del distrito de Tlaxiaco. Centro de Investigaciones y Estudios Superiores en Antropología Sociale: Instituto Estatal de Educación Pública de Oaxaca, Mexico City.

Balkansky, Andrew, Stephen Kowalewski, Verónica Pérez, Thomas Pluckhahn, C. Smith, Laura Stiver, Dmitri Beliaev, John Chamblee, Verenice Heredia, and Roberto Santos

2000 Archaeological Survey in the Mixteca Alta of Oaxaca, Mexico. Journal of Field Archaeology 27(4):365-389.

Bell, Lynne S., Julia Lee-Thorp, and Keith Dobney

2006 Mapping Human Movement Using Stable Oxygen Isotopic Ratio Mass Spectrometry. Journal of the Canadian Society of Forensic Science 39(2):47-54.

Berdan, Frances, and Patricia Anawalt

1997 The Essential Codex Mendoza. University of California Press, Berkeley.

Blitz, Jennifer

1995 Dietary Variability and Social Inequality at Monte Alban, Oaxaca, Mexico. Unpublished Ph.D. dissertation, Department of Anthropology, University of Wisconsin, Madison.

Blomster, Jeffrey P.

2004 Etlatongo: Social Complexity, Interaction, and Village Life in the Mixteca Alta of Oaxaca, Mexico. Case Studies in Archaeology. Thomson Wadsworth, Belmont, California.

Boles, T. Christian, Clyde C. Snow, and Eric Stover

1995 Forensic DNA Testing on Skeletal Remains from Mass Graves: A Pilot Project in Guatemala. Journal of Forensic Sciences 40:349-355.

Borah, Woodrow

1963 El origen de la sericultura en la Mixteca Alta. Historial Mexicana 13(1):1-17.

Buikstra, Jane, and Douglas Ubelaker (editors)

1994 Standards for Data Collection from Human Skeletal Remains. Arkansas Archaeological Survey, Fayetteville.

Calderón Galván, Enriqueta

1988 Teposcolula: breve ensayo monográfico. Secretaría de Desarrollo Económico y Social, Dirección General de Educación, Cultura y Bienestar Social del Gobierno del Estado de Oaxaca, Oaxaca de Juárez.

Castro Morales, Efraín, and Roberto García Moll

1972 Un entierro colectivo en la ciudad de Cholula, Puebla. In Religión en Mesoamérica, XII Mesa Redonda, edited by Jaime Litvak King and Noemí Castillo Tejero, pp. 381-384. Sociedad Mexicana de Antropología, Mexico City.

Chamberlain, Andrew

2006 Demography in Archaeology. Cambridge University Press, New York. 
Chance, John

1978 Race and Class in Colonial Oaxaca. Stanford University Press, Stanford.

Charlton, Thomas H., Cynthia L. Otis Charlton, and Patricia Fournier García

2005 The Basin of Mexico A.D. 1450-1620. In The Postclassic to Spanish Era Transition in Mesoamerica: Archaeological Perspectives, edited by Susan Kepecs and Rani T.Alexander,pp.49-64. University of New Mexico Press, Albuquerque.

Chimalpahin Cuauhtlehuanitzin, Domingo Francisco de San Antón Muñón

1997 [ca. 1621] Codex Chimalpahin, Vol. 2: Society and Politics in Mexico Tenochtitlan, Tlateloco, Texcoco, Culhuacan, and Other Nahua Altepetl in Central Mexico. Translated and edited by Arthur J. O. Anderson and Susan Schroeder. University of Oklahoma Press, Norman.

Cohen, Mark N., Kathleen O'Connor, Marie Danforth, Keith Jacobi, and Carl Armstrong

1994 Health and Death at Tipu. In In the Wake of Contact, edited by Clark Spencer Larsen and George R. Milner, pp. 121-134. Wiley-Liss, New York.

Cook, Noble David

1998 Born to Die. Cambridge University Press, New York.

Cook, Sherburne F., and Woodrow Borah

1968 The Population of the Mixteca Alta: 1520-1960. University of California Press, Berkeley.

Crosby, Alfred W.

1976 Epidemic and Peace, 1918. Greenwood Press, Westport.

Cuevas, Mariano

1975 Documentos inéditos del siglo XVI para la historia de México. Porrúa, Mexico City.

Danforth, Marie Elaine, Keith P. Jacobi, and Mark N. Cohen 1997 Gender and Health Among the Colonial Maya of Tipu, Belize. Ancient Mesoamerica 8:13-22.

de Burgoa, Francisco

1934 [1674] Geográfica descripción. Publicaciones del Archivo General de la Nación, Mexico City.

De la Cruz, Isabel, Angélica González-Oliver, Brian M. Kemp, Juan A. Roman, David Glenn Smith, and Alfonso TorreBlanco

2008 Sex Identification of Children Sacrificed to the Ancient Aztec Rain Gods in Tlateloco. Current Anthropology 493:519-526.

de la Peña, Moisés T.

1950 Problemas sociales y económicos de las Mixtecas. Memorias del Instituto Nacional Indigenista, Vol. 2, No. 1. Mexico City.

de Mendieta, Jerónimo

1945 Historia eclesiástica indiana. Editorial Salvador Chávez Hayhoe, Mexico City.

DeNiro, Michael

1985 Postmortem Preservation and Alteration of In Vivo Bone-Collagen Isotope Ratios in Relation to Paleodietary Reconstruction. Nature 317(6040):806-809.

de Sahagún, Bernardino

1956 Historia general de las cosas de Nueva España, Vol. 3. Editorial Porrúa, Mexico City.

DeWitte, Sharon N., and James W. Wood

2008 Selectivity of Black Death Mortality with Respect to Preexisting Health. Proceedings of the National Academy of Sciences 1055:1436-1441.

Diamond, Jared

1997 Guns, Germs, and Steel. Norton, New York.

Dickinson, Martin F.

1989 Delineating a Site Through Limited Research: The
Mission of San Juan del Puerto (8DU53), Fort George Island, Florida. Florida Anthropologist 42(4):396-409.

Duncan, William N., Andrew K. Balkansky, Kimberly Crawford, Heather A. Lapham, and Nathan J. Meissner

2008 Human Cremation in Mexico 3,000 Years Ago. Proceedings of the National Academy of Sciences USA 105:5315-5320.

Eire, Carlos

1995 From Madrid to Purgatory. Cambridge University Press, New York.

Fields, Sherry Lee

2008 Pestilence and Headcolds. Columbia University Press, New York.

Foster, George M.

1960 Culture and Conquest. Wenner-Gren Foundation for Anthropological Research, New York.

Friedman, Irving, and James R. O'Neil

1977 Compilation of Stable Isotope Fractionation Factors of Geochemical Interest. In Data of Geochemistry, 6th ed., edited by M. Fleischer. U.S. Geological Survey Professional Papers, 440-KK. U.S. Government Printing Office, Washington, D.C.

Gaxiola González, Margarita

1984 Huamelulpan: Un centro urbano de la Mixteca Alta. Colección Científica No. 114. Instituto Nacional de Antropología e Historia, Mexico City.

Gerhard, Peter

1977 Congregaciones de indios en la Nueva España antes de 1570. Historia Mexicana 26:347-395.

1993 A Guide to the Historical Geography of New Spain. University of Oklahoma Press, Norman.

González-Oliver, Angélica, Lourdes Márquez-Morfín, Jóse C. Jiménez, and Alfonso Torre-Blanco

2001 Founding Amerindian Mitochondrial DNA Lineages in Ancient Maya from Xcaret, Quintana Roo. American Journal of Physical Anthropology 116:230-235.

Gowland, Rebecca L., and Andrew Chamberlain

2005 Detecting Plague: Palaeodemographic Characterization of a Catastrophic Death Assemblage. Antiquity 79:146-157.

Graham, Elizabeth, David M. Pendergast, and Grant D. Jones 1989 On the Fringes of Conquest: Maya-Spanish Contact in Colonial Belize. Science 246(4935):1254-1259.

Hodges, Denise C.

1987 Health and Agricultural Intensification in the Valley of Oaxaca, Mexico. American Journal of Physical Anthropology 73(3):323-332.

Hollingsworth, Mary F., and Thomas Henry Hollingsworth 1971 Plague Mortality Rates by Age and Sex in the Parish of St. Boltolph's Without Bishopgate. Population Studies 251:131-146.

Hoppa, Robert D., and James W. Vaupel (editors)

2002 Paleodemography. Cambridge University Press, Cambridge.

Humboldt, Alexander von

1811 Political Essay on the Kingdom of New Spain. Longman, Hurst, Rees, Orme, and Brown, London.

Jacobi, Keith

2000 Last Rites for the Tipu Maya. University of Alabama Press, Tuscaloosa.

Jiménez Moreno, Wigberto, and Salvador Mateos Higuera 1940 Codice de Yanhuitlán. Instituto Nacional de Antropología e Historia, Mexico City.

Kemp, Brian M.

2006 Mesoamerica and Southwest Prehistory, and the Entrance of Humans into the Americas. Unpublished Ph.D. dissertation, Department of Anthropology, University of California, Davis. 
Kemp, Brian M., Angélica González-Oliver, Ripan S. Malhi, Cara Monroe, Kari Britt Schroeder, John McDonough, Gillian Rhett, Andrés Reséndez, Rosenda I. Peñalosa Espinosa, Leonor Buentello Malo, Clara Gorodesky, and David Glenn Smith

2010 Evaluating the Farming/Language Dispersal Hypothesis with Genetic Variation Exhibited by Populations in the Southwest and Mesoamerica. Proceedings of the National Academy of Sciences 10715:6759-6764.

Kemp, Brian M., Andrés Reséndez, Juan Alberto Román Berrelleze, Ripan S. Malhi, and David Glenn Smith 2005 An Analysis of Ancient Aztec mtDNA from Tlatelolco. In Biomolecular Archaeology, edited by David M. Reed, pp. 32-46. Southern Illinois University, Carbondale.

Koch, Joan K.

1983 Mortuary Behavior Patterning and Physical Anthropology in Colonial St. Augustine. In Spanish St. Augustine, edited by Kathleen Deagan, pp. 187-227. Academic Press, New York.

Koch, Paul, Noreen Tuross, and Marilyn Fogel

1997 The Effects of Sample Treatment and Diagenesis on the Isotopic Integrity of Carbonate in Biogenic Hydroxylapatite. Journal of Archaeological Science 24:417-429.

Kolman, Connie, and Noreen Tuross

2000 Ancient DNAAnalysis of Human Populations. American Journal of Physical Anthropology 111:5-23.

Krogman, Wilton Manon, and Mehmet Yasar Iscan

1986 The Human Skeleton in Forensic Medicine. C. C. Thomas Publications, Springfield, Illinois.

Lalueza Fox, Carles, Francisco Luna Calderón, Francesc Calafell, Bernal Morera, and Jaume Bertranpetit

2001 MtDNA from Extinct Tainos and the Peopling of the Caribbean. Annals of Human Genetics 65:137-151.

Lalueza Fox, Carles, M. Thomas P. Gilbert, Antonio J. Martínez Fuentes, Francesc Calafell, and Jaume Bertranpetit

2003 Mitochondrial DNA from Pre-Columbian Ciboneys from Cuba and the Prehistoric Colonization of the Caribbean. American Journal of Physical Anthropology 121:97-108.

Larsen, Clark Spencer

1990 The Archaeology of Mission Santa Catalina de Gaule: 2. Biocultural Interpretations of a Population in Transition. Anthropological Papers of the American Museum of Natural History 68. New York.

1993 On the Frontier of Contact. In The Spanish Missions of La Florida, edited by Bonnie G. McEwan, pp. 322-356. University Press of Florida, Gainesville.

Larsen, Clark Spencer, Margaret J. Schoeninger, Dale L. Hutchinson, Katherine F. Russell, and Christopher B. Ruff 1990 Beyond Demographic Collapse: Biological Adaptation and Change in Native Populations of La Florida. In Columbian Consequences, Vol.2: Archaeological and Historical Perspectives on the Spanish Borderlands East, edited by David Hurst Thomas, pp. 409-428. Smithsonian Institution Press, Washington, D.C.

LeBlanc, Steven, Lori S. Cobb Kreisman, Brian M. Kemp, Francis E. Smiley, Shawn W. Carlyle, Anna N. Dhody, and Thomas Benjamin

2007 Quids and Aprons. Journal of Field Archaeology 32:161-175

Lee, Thomas A.

1979 Coapa, Chiapas: A Sixteenth-Century Coxoh Maya Village on the Camino Real. In Maya Archaeology and Ethnohistory, edited by Norman Hammond and Gordon R. Willey, pp. 208-222. University of Texas Press, Austin. Longinelli, Antonio

1984 Oxygen Isotopes in Mammal Bone Phosphate: A New
Research Tool for Paleohydrological and Paleoclimatological Research? Geochimica et Cosmochimica Acta 48:385-390.

Lorenz, Joseph G., and David Glenn Smith

1996 Distribution of Four Founding mtDNA Haplogroups Among Native North Americans. American Journal of Physical Anthropology 101:307-323.

Lovejoy, C. Owen, Richard S. Meindl, Thomas R. Pryzbeck, and Robert P. Mensforth

1985 Chronological Metamorphosis of the Auricular Surface of the Ilium. American Journal of Physical Anthropology 68:15-28.

Lovell, W. George

1992 Disease and Depopulation in Early Colonial Guatemala. In Secret Judgments of God, edited by Noble David Cook and George Lovell, pp. 49-83. University of Oklahoma Press, Norman.

Luz, Boaz, and Yehoshua Kolodny

1989 Oxygen Isotope Variations in Bone Phosphate. Applied Geochemistry 4:317-323.

MacLeod, Murdo J.

1973 Spanish Central America: A Socioeconomic History, 1520-1720. University of California Press, Berkeley.

Malhi, Ripan S., Jason A. Eshleman, Jonathan A. Greenberg, Deborah A. Weiss, Beth Schultz Shook, Frederika A. Kaestle, Joseph G. Lorenz, Brian M. Kemp, John R. Johnson, and David Glenn Smith

2002 The Structure of Diversity Within New World Mitochondrial DNA Haplogroups. American Journal of Human Genetics 70:905-919.

Malhi, Ripan S., Holly M. Mortensen, Jason A. Eshleman, Brian M. Kemp, Joseph G. Lorenz, Frederika Kaestle, John R. Johnson, Clara Gorodezky, and David Glenn Smith

2003 Native American mtDNA Prehistory in the American Southwest. American Journal of Physical Anthropology 120:108-124.

Malvido, Elsa

1997 Civilizados o salvajes. In El cuerpo humano y su tratamiento morturorio, edited by Elsa Malvido, Grégory Pareira, and Vera Tiesler, pp. 29-49. Instituto Nacional de Antropología e Historia, Mexico City.

Malvido, Elsa, Josefina Mansilla, and José A. Pompa

1986 Un cementerio indígena del siglo XVI en Huexotla, Estado de México. Trace 10:39-51.

Malvido, Elsa, and Carlos Viesca

1985 La epidemia de cocoliztli de 1576. Historias México, D.F. 11:27-33.

Mansell, Eugenia B., Robert H. Tykot, David A. Friedel, Bruce H. Dahlin, and Traci Arden

2006 Early to Terminal Classic Maya Diet in the Northern Lowlands of the Yucatan (Mexico). In Histories of Maize, edited by John Staller, Robert Tykot, and Bruce Benz,pp. 173-185. Academic Press, New York.

Mansilla, Josefina, Carmen María Pijoan, José A. Pompa, and Delia Villegas

1992 Los entierros primarios del Templo de San Jerónimo, Ciudad de México (Temporada 1976): estudio de los indicadores de las agresiones ambientales. In Antropología Física Anuario 1991, edited by María Teresa Jáen, José Luis Fernández Torres, and Antonio Pompa y Padilla, pp. 121-149. Instituto Nacional de Antropología e Historia, Mexico City.

Mansilla, Josefina, and José Pompa

1992 Un cementerio indígena del siglo XVI en Huexotla. In Antropología Física Anuario 1991, edited by María Teresa Jáen, José Luis Fernández Torres, and Antonio Pompa y Padilla, pp. 93-119. Instituto Nacional de Antropología e Historia, Mexico City. 
Margerison, Beverley J., and Christopher Knüsel

2002 Paleodemographic Comparison of a Catastrophic and an Attritional Death Assemblage. American Journal of Physical Anthropology 119:134-143.

Marr, John S., and James B. Kiracofe 2000 Was the Huey Cocoliztli a Haemorrhagic Fever? Medical History 44:341-362.

McCafferty, Geoffrey G.

2000 The Cholula Massacre: Factional Histories and Archaeology of the Spanish Conquest. In The Entangled Past: Integrating History and Archaeology, edited by M. Boyd, J.C. Erwin, and M. Hendrickson, pp. 347-359. Proceedings of the 30th Annual Chacmool Conference, Calgary.

Melville, Elinor G. K.

1994 A Plague of Sheep: Environmental Consequences of the Conquest of Mexico. Cambridge University Press, New York.

Miller, Arthur G., and Nancy Farriss

1979 Religious Syncretism in Colonial Yucatan: The Archaeological and Ethnohistorical Evidence from Tancah, Quintana Roo. In Maya Archaeology and Ethnohistory, edited by Norman Hammond and Gordon R. Willey, pp. 223-240. University of Texas Press, Austin.

Miranda, José

1958 Orígens de la ganadería en la Mixteca. In Miscellanea, Paul Rivet octogenario dictata, Vol.2. Mexico City.

Motolinía (aka Benavente, Toribio de)

1971 Memoriales o libro de las cosas de la Nueva España y de los naturales della. Universidad Nacional Autónoma de México, Mexico City.

Mullen, Robert James

1975 Dominican Architecture in Sixteenth Century Oaxaca. Arizona State University, Tempe.

Newson, Linda A.

1992 Old World Epidemics in Early Colonial Ecuador. In Secret Judgments of God, edited by Noble David Cook and W. George Lovell, pp. 84-112. University of Oklahoma Press, Norman.

Ocaña del Río, Bertha

1985 Estudio del material óseo procedente del Convento de San Gabriel, Cholula, Puebla. In Avances en Antropología Física, Cuaderno de Trabajo 2, edited by Zaíd Lagunas Rodríguez,pp.73-80. Instituto Nacional de Antropología e Historia, Mexico City.

Orellana, Sandra L.

1987 Indian Medicine in Highland Guatemala. University of New Mexico Press, Albuquerque.

Oudijk, Michael R., and Matthew Restall

2007 Mesoamerican Conquistadors in the Sixteenth Century. In Indian Conquistadors, edited by Laura E. Matthew and Michael R. Oudijk, pp. 28-64. University of Oklahoma Press, Norman.

Paso y Troncoso, Francisco del

1981 Relaciones geográficas de Oaxaca. Editorial Innovación, Mexico City.

Pellicer, Sergio Navarrete

1990 Las transformaciones de la economía indígena en Michoacán. In Agricultura indígena, edited by Teresa Rojas Rabiela, pp. 109-127. Centro de Investigaciones y Estudios Superiores en Antropología Social, Mexico City.

Peñaloza-Espinosa, Rosenda I., Diego Arenas-Aranda, Ricardo M. Cerda-Flores, Leonor Buentello-Malo, Gerardo González-Valencia, Javier Torres, Berenice Álvarez, Irma Mendoza, Mario Flores, Lucila Sandoval,Francisco Loeza, Irma Ramos, Leopoldo Muñoz, and Fabio Salamanca

2007 Characterization of mtDNA Haplogroups in 14 Mexican Indigenous Populations. Human Biology 793:313-320.
Pendergast, David M.

1991 The Southern Maya Lowlands Contact Experience: The View from Lamanai, Belize. In Columbian Consequences, Vol. 3: The Spanish Borderlands in Pan-American Perspective, edited by David Hurst Thomas, pp. 337-354. Smithsonian Institution Press, Washington, D.C.

Pérez Ortiz, Alfonso

2003 Tierra de brumas. Plaza y Valdés, Mexico City.

Pérez Rodríguez, Verónica

2006 States and Households: The Social Organization of Terrace Agriculture in Postclassic Mixteca Alta, Oaxaca, Mexico. Latin American Antiquity 17(1):3-22.

Pérez Rodríguez, Verónica, Kirk C. Anderson, and Margaret K. Neff

2011 The Cerro Jazmín Archaeological Project: Investigating Prehispanic Urbanism and Its Environmental Impact in the Mixteca Alta, Oaxaca, Mexico. Journal of Field Archaeology 36(2):83-99.

Prem, Hanns

1992 Disease Outbreaks in Central Mexico During the Sixteenth Century. In Secret Judgments of God, edited by Noble David Cook and W. George Lovell, pp. 20-48. University of Oklahoma Press, Norman.

Price, T. Douglas, James H. Burton, Robert Sharer, Jane Buikstra, Lori Wright, Loa P. Traxler, and Katherine A. Miller 2010 Kings and Commoners at Copan. Journal of Anthropological Archaeology 29:15-32.

Quinn, Rhonda L., Bryan D. Tucker, and John Krigbaum

2008 Diet and Mobility in Middle Archaic Florida: Stable Isotopic and Faunal Evidence from the Harris Creek Archaeological Site 8Vo24, Tick Island. Journal of Archaeological Science 358:2346-2356.

Restall, Matthew, Lisa Sousa, and Kevin Terraciano

2001 Mesoamerican Voices: Colonial Mexico, Oaxaca, Yucatan, and Guatemala. Cambridge University Press, New York.

Riquer, Jorge Silva

1990 La agricultura indígena en el Valle de Nochixtlan en el siglo XVI. In Agricultura indígena, edited by Theresa Rojas Rabiela, pp. 187-196. Centro de Investigaciones y Estudios Superiores en Antropología Social, Mexico City.

Robles García, Nelly

1988 Las Unidades Domésticas del Preclásico Superior en la Mixteca Alta. BAR International Series 407. British Archaeological Reports, Oxford.

Robles García, Nelly, and Ronald Spores

2004 Pueblo Viejo de Teposcolula Yucundaa, proyecto arqueológico: primera temporada. Cuadernos de Teposcolula 3. Report submitted to Consejo de Arqueología del Instituto Nacional de Antropología e Historia de Mexico, Mexico City.

2005 Pueblo Viejo de Teposcolula Yucundaa, proyecto arqueológico: primera temporada. Report submitted to Consejo de Arqueología del Instituto Nacional de Antropología e Historia de Mexico, Mexico City.

2006 Pueblo Viejo de Teposcolula Yucundaa, proyecto arqueológico: primera temporada. Report submitted to Consejo de Arqueología del Instituto Nacional de Antropología e Historia de Mexico, Mexico City.

Romano Pacheco, Arturo, and María Teresa Jaén Esquivel 1985 Proyecto: Ex-convento de San Jerónimo: éstudio de una muestra de la población de la Ciudad de México, siglos XVI a XIX. In Avances en antropología física. Cuaderno de Trabajo 2, pp. 87-93. Instituto Nacional de Antropología e Historia, Mexico City.

Romero Frizzi, Maria de los Ángeles

1990 Economía y vida de los Españoles en la Mixteca Alta. 
Instituto Nacional de Antropología e Historia, Mexico City.

Rush, Alfred C

1941 Death and Burial in Christian Antiquity. Catholic University of America Press, Washington, D.C.

Salas Cuesta, María Elena

1982 La población de México Tenochtitlan. Colección Científica-Antropología Física No. 126. Instituto Nacional de Antropología y Historia, Mexico City.

Schroeder, Hannes, Tamsin C. O'Connell, Jane E. Evans, Kristrina A. Shuler, and Robert E. M. Hedges

2009 Trans-Atlantic Slavery. American Journal of Physical Anthropology 139:547-557.

Schurr, Theodore G.

2004 The Peopling of the New World. Annual Review of Anthropology 33:551-583.

Scott, G. Richard, and Christy G. Turner, II

1997 The Anthropology of Modern Human Teeth. Cambridge University Press, Cambridge.

Signoli, Michel

2006 Etude anthropologique de crises démographiques en contexte epidémique. Archaeopress, Oxford.

Signoli, Michel, Isabelle Seguy, Jean-Noel Biraben, Olivier Dutour, and Paul Belle

2002 Paleodemography and Historical Demography in the Context of an Epidemic Plague in Provence in the Eighteenth Century. Population 576:829-854.

Smith, David Glenn, Ripan S. Malhi, Jason Eshleman, Joseph G. Lorenz, and Frederika Kaestle

1999 Distribution of mtDNA Haplogroup XAmong Native North Americans. American Journal of Physical Anthropology 110:271-284.

Soren, David

2003 Can Archaeologists Excavate Evidence of Malaria? World Archaeology 352:193-209.

Spores, Ronald

1967 The Mixtec Kings and Their Peoples. University of Oklahoma Press, Norman.

Spores, Ronald, and Nelly Robles García

2007 A Prehispanic Postclassic Capital Center in Colonial Transition. Latin American Antiquity 183:333-353.

Stiver, Laura

2001 Prehispanic Mixtec Settlement and State in the Teposcolula Valley of Oaxaca, Mexico. Unpublished Ph.D. dissertation, Department of Anthropology, Vanderbilt University, Nashville.

Terraciano, Kevin

2001 The Mixtecs of Colonial Oaxaca. Stanford University Press, Stanford.

Tiesler, Vera, Andrea Cucina, and Arturo Romero Pacheco

2004 Who Was the Red Queen? Identity of the Female Maya Dignitary from the Sarcophagus Tomb of Temple XIII, Palenque, Mexico. Journal of Comparative Human Biology 55(1-2):65-76.

Tiesler, Viera, and Pilar Zabala

2010 Dying in the Colonies: Death, Burial, and Mortuary Patterning in Campeche's Main Plaza. In Natives, Europeans, and Africans in Colonial Campeche, edited by Vera Tiesler, Pilar Zabala, and Andrea Cucina, pp. 70-94. University Press of Florida, Gainesville.

Torroni, Antonio, Yu-Shen Chen, Ornella Semino, Augusta Silvana Santachiara-Beneceretti, C. Ronald Scott, Marie T. Lott, Marcus Winter, and Douglas C. Wallace

1994 MtDNA and Y-Chromosome Polymorphisms in Four Native American Populations from Southern Mexico. American Journal of Human Genetics 54:303-318.
Torroni, Antonio, Theodore G. Schurr, Margaret F. Cabell, Michael D. Brown, James V. Neel, Merethe Larsen, David Glenn Smith, Carlos M. Vullo, and Douglas C. Wallace

1993 Asian Affinities and Continental Radiation of the Four Founding Native American mtDNAs. American Journal of Human Genetics 533:563-590.

Torroni,Antonio, Theodore G. Schurr, Chi-Chuan Yang,Emöke Szathmary, Robert C. Williams, Moses S. Schanfield, Gary A. Troup, William C. Knowler, Dale N. Lawrence, Kenneth $M$. Weiss, and Douglas C. Wallace

1992 Native American Mitochondrial DNA Analysis Indicates that the Amerind and the Nadene Populations Were Founded by Two Independent Migrations. Genetics 130:153-162.

Trueman, Clive, Anna K. Behrensmeyer, Noreen Tuross, and Steve Weiner

2004 Mineralogical and Compositional Changes in Bones Exposed on Soil Surfaces in Amboseli National Park, Kenya. Journal of Archaeological Science 31:721-739.

Ubelaker, Douglas

1989 Human Skeletal Remains. 2nd ed. Taraxacum, Washington, D.C.

Vences Vidal, Magdalena

2000 Evangelización y arquitectura dominicana en Coixtlahuaca Oaxaca México. Editorial San Esteban, Salamanca.

Waldron, H. A

2001 Are Plague Pits of Particular Use to Palaeoepidemiologists? International Journal of Epidemiology 30:104-108.

Warinner, Christina

2010 Life and Death at Teposcolula Yucundaa. Unpublished Ph.D. dissertation, Department of Anthropology, Harvard University, Cambridge.

Warinner, Christina, Nelly Robles García, and Noreen Tuross 2012 Maize, Beans and the Floral Isotopic Diversity of Highland Oaxaca, Mexico. Journal of Archaeological Science, forthcoming.

Warinner, Christina, and Noreen Tuross

2009 Alkaline Cooking and Stable Isotope Diet-Tissue Discrimination in Swine. Journal of Archaeological Science 368:1690-1697.

2010 Tissue Isotopic Enrichment Associated with Growth Depression in a Pig. American Journal of Physical Anthropology 141:486-493.

Werner, Roland A., and Willi Brand

2001 Referencing Strategies and Techniques in Stable Isotope Ratio Analysis. Rapid Communications in Mass Spectrometry 15:501-519.

White, Christine D., Michael W. Spence, Fred J. Longstaffe, and Kimberley Law

2000 Testing the Nature of Teotihuacan Imperialism at Kaminaljuyu Using Phosphate Oxygen Isotope Ratios. Journal of Anthropological Research 564:535-558.

White, Christine D., Lori E. Wright, and David M. Pendergast 1994 Biological Disruption in the Early Colonial Period at Lamanai. In In the Wake of Contact: Biological Responses to Conquest, edited by Clark Spencer Larsen and George R. Milner, pp. 135-146. Wiley-Liss, New York.

Whittington, Stephen L.

1989 Characteristics of Demography and Disease in LowStatus Maya from Classic Period Copan, Honduras. Unpublished Ph.D. dissertation, Department of Anthropology, Pennsylvania State University, University Park.

Wright, Lori, and Henry P. Schwarcz

1998 Stable Carbon and Oxygen Isotopes in Human Tooth 
Enamel. American Journal of Physical Anthropology 106:1-18.

Zavala, Silvio

1982 Asientos de la gobernación de la Nueva España. Archivo General de la Nación, Mexico City.

Zinsser, Hans

1934 Rats, Lice, and History. Little Brown, Boston.

\section{Note}

1. The current institutional affiliation for Christina Warinner is as follows: Department of Anthropology, University of Oklahoma, Norman, OK 73019 (christina.warinner@ou.edu).

2. Teposcolula Yucundaa is a hybridized name that reflects the Mixtec, Aztec, and Spanish heritage of the site. Teposcolula is the hispanicized form of a Nahuatl (Aztec) word meaning "Place of the copper axes," which has several spelling variants in the colonial record, including
Tepozcollollan (Chimalpahin 1997 [ca. 1621]) and Tepuzculula (Berdan and Anawalt 1997). In Mixtec, the town was called Yucundaa (Jiménez Moreno and Mateos Higuera 1940), which may be translated as "On the plain of the hill" or "Blue hill" (Alavez 1988:92; Alavez Chávez 2006:32; Restall et al. 2001:139). The Spanish renamed the town San Pablo Teposcolula (Jiménez Moreno and Mateos Higuera 1940), a name also used to refer to the town after its relocation to the valley (Calderón Galván 1988). By the eighteenth century, the new town had acquired a second patron saint and has since borne the name San Pedro y San Pablo Teposcolula. Today, the mountaintop archaeological site is known as Teposcolula Yucundaa, although locals generally refer to it as Pueblo Viejo, or "Old Town."

Submitted: April 15, 2011; Revised: August 30, 2012; Accepted: September 20, 2012. 